Jeroen Touwen

\title{
VARIETIES OF CAPITALISM EN DE NEDERLANDSE ECONOMIE IN DE PERIODE 1950-2000
}

\begin{abstract}
Varieties of capitalism and the Dutch economy in the period 1950-2000 This article introduces the theory of 'varieties of capitalism' (Hall and Soskice) and its context of the study of comparative capitalism. What is the position of the Dutch economy within the framework of 'varieties of capitalism'? Reviewing five institutional subspheres, I try to outline the institutional complementarities in the Dutch case. This leads to an evaluation of the theory with regard to its use in analysing the Dutch economy. In many aspects the Dutch economy is a 'coordinated market economy'. However, since 1980, increasing globalisation and liberal policies exert a strong influence on the characteristics of the Dutch market economy. Taxonomies like 'varieties of capitalism' contribute to our insight into the effects of different economic institutions. These regulatory mechanisms may be rooted in path-dependent evolution and institutional complementarities, but the theory fails to explain transformations over time.
\end{abstract}

De varieties of capitalism-theorie van P.A. Hall en D. Soskice krijgt momenteel veel aandacht in het debat over verschillende vormen van kapitalisme in de politicologie. ${ }^{\mathrm{I}}$ Deze theorie analyseert de verschillen tussen markteconomieën waarbij de aandacht uitgaat naar de aanbodzijde. ${ }^{2}$ In deze theorie staan twee vragen centraal: op welke manier vinden concurrentie en marktwerking plaats en hoe laten de economische actoren (dit zijn bedrijven, organisaties, overheidsinstanties, kortom, alle spelers in het economische veld) zich beïnvloeden door hun institutionele omgeving?

Volgens de varieties of capitalism-theorie zijn er twee ideaaltypen van vrije markteconomieën, waarbij de één sterk liberaal is en de ander functioneert

\footnotetext{
1. Peter A. Hall en David Soskice, 'An introduction to varieties of capitalism', in: Varieties of capitalism. The institutional foundations of comparative advantage (Oxford 200I) I-68.

2. De aandacht gaat dus niet naar typische vraagzijde-aspecten, zoals inkomensoverdrachten, verzorgingsstaatregime of loonpolitiek; het gaat als het ware om de werking van de motor van de economie in de verschillende constellaties.
}

TIJDSCHRIFT VOOR SOCIALE EN ECONOMISCHE GESCHIEDENIS 3 [2006] NR. I, PP. 73-IO4 
binnen een netwerk van allerlei vormen van coördinatie, die samen de vrije markt reguleren. Het ene extreem, de Liberal Market Economy (LM E), is geïnspireerd door de situatie in de Verenigde Staten en het andere extreem, de Coordinated Market Economy ( $\mathrm{CM} \mathrm{E}$ ), is gebaseerd op Duitsland, zoals we hieronder zullen zien. De varieties of capitalism-theorie stelt dat de economische instituties in een land bepalend zijn voor het gedrag van de actoren op verschillende deelterreinen. Door landen in te delen op grond van hun institutionele kenmerken ontstaat er een classificatie in LME's en CME's; de verschillende institutionele kenmerken komen namelijk voor in clusters, omdat de ene institutie het ontstaan en voortduren van een andere institutie versterkt. Bij elke beslissing van een economische actor speelt de context mee, maar ook de eerder genomen beslissingen (en dus ook de reeds bestaande instituties).

Dit artikel geeft een samenvatting van de varieties of capitalism-theorie en bekijkt hoe Nederland hierin kan worden gepositioneerd. Omdat de varieties of capitalism-theorie niet alleen criteria voor een classificatie aanreikt maar ook een verklaringsmodel wil zijn voor het ontstaan en voortbestaan van verschillende soorten kapitalisme, verdient deze de belangstelling van de historicus: padafhankelijkheid is in de theorie een essentieel element, waardoor ook de historische economische ontwikkeling en het gevoerde economisch beleid een rol spelen. Biedt de theorie houvast om de economische ontwikkeling te analyseren, en zo ja, welke inzichten levert dat op?

Volgens de theorie leidt overleg tussen groepen met verschillende belangen in een bepaald deelgebied tot een specifieke sociale infrastructuur die vervolgens zal leiden tot overleg en coördinatie in ándere deelgebieden. Evenzo zal een hoge mate van marktwerking en nadruk op eigenbelang leiden tot verminderde coördinatie op álle deelterreinen van de economie. Het is namelijk waarschijnlijk (en economisch gunstig) dat de beweging in deelgebieden van de economie dezelfde kant opgaat. Dit inzicht staat in de varieties of capitalismtheorie centraal; er wordt zelfs gesteld dat de uitersten van het spectrum, de LME en de CME, de beste economische prestaties leveren. Mengvormen die zich tussen de twee ideaaltypen in bevinden, zijn volgens deze theorie minder levensvatbaar in een competitieve wereldeconomie en zullen een lagere economische groei tonen.

Dit artikel is als volgt opgebouwd. Na een uiteenzetting over de theorie wordt de Nederlandse casus geanalyseerd met behulp van bestaande empirische vergelijkingen tussen landen uit de literatuur. Vervolgens worden de vijf institutionele deelgebieden uit de theorie beschouwd. Er wordt aandacht besteed aan de veranderingen op hoofdlijnen die hierin optraden in Nederland gedurende de laatste helft van de twintigste eeuw. Dit geeft aanleiding tot enkele opmerkingen over de wijze waarop met veranderingen wordt omgegaan in de varieties of capitalism-theorie. 


\section{Instituties en cultuur}

De vrije markt zoals geformuleerd in het (neo)klassieke economische model wordt in zijn functioneren beïnvloed door instituties. De regels, wetten, instellingen en organisaties die een effect hebben op het economische verkeer noemen we formele instituties. De normen en waarden, de door traditie overgeleverde gebruiken die een rol spelen in de economie vormen de zogenaamde informele instituties. De eerste kunnen nauwgezet in kaart worden gebracht en hun effect kan worden geanalyseerd. De tweede zijn moeilijker te analyseren, want ze hangen nauw samen met het ongrijpbare begrip 'cultuur'. ${ }^{3}$ Hoewel in de economie en de economische geschiedenis het begrip 'institutie' niet meer is weg te denken, is niet iedereen overtuigd dat hiermee de invloed van cultuur op de economie helder en systematisch kan worden geanalyseerd. Zo schrijft Vries: 'Institutional economics may ask the right questions, they have not come up with a set of systematically interrelated answers that can be integrated in a new paradigm and that allows us to throw away the neo-classical rational-choice approach'. ${ }^{4}$

Het interessante van de varieties of capitalism-theorie is dat een verband wordt gelegd tussen het gedrag van de bedrijven en de institutionele omgeving waarin zij zich bevinden. In de political economy, een subdiscipline van de politieke wetenschappen, wordt de laatste jaren veel gedebatteerd over de overlevingskansen van verschillende vormen van kapitalistische markteconomieën. Hierin staat in feite hetzelfde onderwerp centraal, namelijk de verklaring van het bestaan van verschillende vormen van succesvolle markteconomieën op basis van hun specifieke instituties en culturele kenmerken. Regulerende en coördinerende instituties bepalen hoe 'vrij' de vrije markt is, doordat zij in de praktijk dikwijls de concurrentie beperken. Maar zij hoeven niet alleen belemmerend te werken voor de economische spelers. Ze kunnen ook een voordeel opleveren, met name in allerlei transactiekosten: informatie is eenvoudiger te verkrijgen, hoogopgeleid personeel verbindt zich langer aan één bedrijf en kapitaal kan eenvoudiger worden aangetrokken. Dit geldt ook op macroniveau: beleidsalternatieven met een sociaal karakter krijgen een kans omdat verschillende deelbelangen zorgvuldiger worden afgewogen. De afgelopen vijftig jaar hebben de Verenigde Staten en Duitsland (en de andere West-Europese economieën en Japan) gedemonstreerd dat verschillende

3. Over het moeilijk te operationaliseren begrip 'cultuur' is nog niet lang geleden een zestal bijdragen verschenen in een van de voorlopers van dit tijdschrift: NEHA-Jaarboek voor economische, bedrijfs- en techniekgeschiedenis 64 (200I) 6-I23. Bijdragen van Paul M.M. Klep, P.H.H. Vries, J.R. Goody, Arthur P. Wolf, Willem Frijhhoff en John F. Wilson.

4. P.H.H. Vries, 'The role of culture and institutions in economic history: can economics be of any help?', in: NEHA-Jaarboek voor economische, bedrijfs- en techniekgeschiedenis 64 (200I) 28-60, aldaar 66 . 
modellen bestaansrecht hebben en dat convergentie naar één type markteconomie niet waarschijnlijk is.

In de varieties of capitalism-theorie wordt juist benadrukt dat de toepassing van marktgericht neoliberaal economisch beleid, dat voortkomt uit het neoklassieke paradigma van prijsvorming, niet vanzelf leidt tot één economisch model dat moet worden nagestreefd. ${ }^{5}$ Er is zelfs sprake van enige rehabilitatie van de Europese economieën, waar zowel de coördinatiegraad als de collectieve uitgaven hoog zijn. Hoewel de economische groei in de West-Europese landen sinds de tweede helft van de jaren negentig enigszins is achtergebleven bij die in de Verenigde Staten en China, is zowel de arbeidsproductiviteit als de kwaliteit van leven in Europa hoog. Ook schroomt men in de meeste landen niet om de noodzakelijke veranderingen door te voeren, hetgeen door een gezaghebbend econoom recentelijk werd beschreven als: 'Europe may be converging to a more efficient European model rather than to the U.s. model'. ${ }^{6}$ Verschillende malen is aangetoond dat een structureel hoog niveau van sociale uitgaven niet noodzakelijk slecht is voor economische groei of een gunstige concurrentiepositie. ${ }^{7}$ Hoewel het debat over convergentie nog niet is beslecht, zijn er talloze onderzoeken die aangeven dat er vooralsnog weinig reden is om te beweren dat één economisch model het van alle andere zal winnen.

\section{Criteria voor 'liberaal' en 'gecoördineerd'}

In de ideale LM E zorgt de markt voor coördinatie op vrijwel alle deelgebieden. Zo zijn behalve goederen ook zaken als informatie, onderwijs, uitvindingen en specifieke vaardigheden op de markt te koop. Het accent ligt hier op concurrentie en kortetermijnwinst, hetgeen kan leiden tot efficiëntie door de 'tucht van de markt'. Er is echter ook meer wantrouwen onder bedrijven en organisaties, hetgeen weer transactiekosten oplevert. In de c M E worden de contacten tussen de bedrijven niet uitsluitend door vraag en aanbod bepaald en is er meer nietmarktgerichte 'strategische interactie'. Hierdoor liggen de winsten in deze landen doorgaans wat lager maar is er meer ruimte voor samenwerking, informatie-uitwisseling en sociaal beleid. ${ }^{8}$

5. Met andere woorden: Amerika is niet de norm en het neoklassieke model is niet zaligmakend.

6. Olivier Blanchard, 'The economic future of Europe', in: Journal of Economic Perspectives I8:4 (2004) 3-26, aldaar 24.

7. Zie bijvoorbeeld Peter H. Lindert, Growing public: social spending andeconomic growth since the eighteenth century. Twee delen (Cambridge 2004); en ook Peter Katzenstein, Small states in world markets (Londen I985).

8. Hall en Soskice, 'Introduction', 8-9, 33-44. 
Hall en Soskice analyseren hoe bedrijven en organisaties hun coördinatieproblemen oplossen: via de markt of via overleg. Hiertoe onderscheiden ze vijf institutionele deelgebieden: ${ }^{9}$

(I) de houding van bedrijven ten opzichte van de vakbonden en de overheid in onderhandelingen over lonen en arbeidsomstandigheden; ${ }^{\text {i० }}$

(2) de mate waarin bedrijven investeren in beroepsopleidingen en trainingen voor hun personeel;

(3) de wijze waarop het bedrijf wordt bestuurd (corporate governance), hetgeen ook direct samenhangt met de wijze waarop kapitaal wordt aangetrokken: als het bedrijf kapitaal aantrekt via de beurs, zullen aandeelhouders invloed (kunnen) uitoefenen op het beleid van het bedrijf. Als financiering tot stand komt via langlopende bankleningen kan een ander, bijvoorbeeld meer op continuiteit gericht beleid gevoerd worden; ${ }^{\text {II }}$

(4) de mate waarin netwerken bestaan met andere bedrijven, waarin informatie-uitwisseling, coördinatie, afstemming of samenwerking plaatsvindt;

(5) de houding ten opzichte van het eigen personeel, zoals de mate waarin werknemers bij de besluitvorming worden betrokken en deelgenoot worden gemaakt van potentieel gevoelige informatie (het gaat hier om de tegenstelling tussen het kweken van betrokken en gemotiveerde werknemers versus het risico van werknemers die overlopen naar de concurrent of chantage door dwarsliggers).

De grenzen tussen deze themagebieden zijn vrij vaag. Opvallend is dat sommige deelgebieden veel te maken hebben met de wijze waarop wordt omgegaan met arbeid en de arbeidsverhoudingen ((I), (2) en (5)) en dat alle deelgebieden sterk afhankelijk zijn van corporate governance. ${ }^{\mathrm{I2}}$ Wanneer in een land bijvoorbeeld een ondernemingsraad wettelijk verplicht is, valt deze institutie dan onder de arbeidsverhoudingen (I), onder corporate governance (3) of onder personeelszaken bij het specifieke bedrijf (5)? Toch heeft het onderscheiden van deze 'coördinatiesferen' een belangrijke functie. Hall en Soskice

\section{Ibidem, 7 .}

10. Arbeidsverhoudingen staan per definitie centraal in de studie naar het neo-corporatisme, maar volgens Hall en Soskice heeft dat als tekortkoming dat de 'emphasis on the trade union movement underplays the role that firms and employer organizations play in the coordination of the economy'. Hall en Soskice, 'Introduction', 4. Dit neemt niet weg dat studies naar corporatisme een goede basis vormen voor dit soort onderzoek. Een studie die de rol van werkgevers centraal stelt is: Peter A. Swenson, Capitalists against markets. The making oflabor markets and welfare states in the United States and Sweden (Oxford en New York 2002).

11. Familiebedrijven worden door Hall en Soskice niet expliciet genoemd maar hun effect op kenmerken van de nationale economie zou in dit deelgebied aandacht verdienen.

12. Zie ook Bruno Amable, 'Institutional complementarity and diversity of social systems of innovation and production', in: Review of International Political Economy 7:4 (2000) 645-687, aldaar 667 . 
stellen dat de wijze waarop coördinatieproblemen worden opgelost in elk deelgebied van invloed is op de wijze waarop de problemen in andere deelgebieden worden opgelost. Zo kan de kracht van de coördinatiemechanismes 'markt' en 'overleg' worden verklaard.

De onderlinge beïnvloeding van de verschillende institutionele deelgebieden wordt geanalyseerd met behulp van het concept institutional complementarities. Bepaalde instituties oefenen een invloed uit op de instituties in andere deelgebieden van de economie. ${ }^{\mathrm{I3}}$ De term is bedacht naar analogie van de complementaire goederen in de economie die elkaars verkoop versterken, zoals bijvoorbeeld brood en margarine. In sommige landen verstrekken bijvoorbeeld industriebanken kapitaal in langetermijnleningen en op voorwaarden die niet van kortetermijnwinst afhankelijk zijn. In deze landen zullen de ondernemingen eerder geneigd zijn om langdurige arbeidscontracten af te sluiten met hun werknemers en te investeren in scholing en training. In landen daarentegen waar het beschikbare kapitaal voornamelijk afkomstig is van beleggers, die dividenduitkeringen willen ontvangen en de waarde van hun aandeel belangrijk vinden, is het omgekeerde het geval. Hier is het belangrijk voor de onderneming om bij omzetvermindering snel personeel te kunnen ontslaan om de kosten te drukken. Ook zal er minder in beroepsopleidingen worden geïnvesteerd. Wel kunnen de bedrijven in deze landen op korte termijn via de beurs veel geld binnenhalen voor een veelbelovende uitvinding. $Z$ o is er dus een wisselwerking tussen de financiële sector en de arbeidsverhoudingen. ${ }^{14}$ Dit verband is empirisch aangetoond met gebruik van een OEso-indicator voor arbeidsbescherming op basis van de late jaren I980 en de late jaren I990. Wanneer deze indicator in een grafiek wordt uitgezet tegen het nationale aandelenkapitaal als percentage van het в в р, dan blijken de achttien ов so-landen in twee clusters gegroepeerd te zijn. Landen met een sterk ontwikkelde kapitaalmarkt kennen weinig ontslagbescherming, en andersom. ${ }^{\text {I5 }}$

Ook tussen de arbeidsverhoudingen en het beleid ten opzichte van opleiding en training is een duidelijk verband. Bedrijven in LM E's zijn relatief huiverachtig om te investeren in opleidingen voor hun werknemers, aangezien de mobiliteit op de arbeidsmarkt in dit type economie veel groter is. Omdat er minder wordt samengewerkt tussen bedrijven, is het risico groter dat werknemers met specifieke vaardigheden worden weggekocht door de concurrent, die op deze wijze kennis en innovatie in huis kan halen.

Hall en Soskice benadrukken dat zij een 'relational view of the firm' hanteren. Een onderneming ziet zich geplaatst tegenover allerlei coördinatiepro-

13. Hall en Soskice, 'Introduction', 6-7.

14. Ibidem, I8-I9, 57.

15. Hall en Soskice, 'Introduction', I9; Margarita Estevez-Abe, Torben Iversen en David Soskice, 'Social protection and the formation of labour skills: a reinterpretation of the welfare state', in: Hall en Soskice, Varieties of capitalism, I45-I83, aldaar I64-I65. 
blemen, zowel externe als interne, die betrekking hebben op klanten, toeleveranciers, personeel, vakbonden, regulerende overheidsinstanties, de concurrentie en werkgeversverbonden. ${ }^{16}$ Het succes van de bedrijfsvoering hangt in sterke mate af van het oplossen van deze coördinatieproblemen.

Als bedrijven in een 'gecoördineerde' omgeving opereren, waarin de relationele problemen niet alleen door de markt maar tevens door vormen van samenwerking worden opgelost, dan moeten er ook oplossingen gevonden worden voor vertrouwensdilemma's die zich hierbij voordoen, zoals het freerider probleem en het prisoners' dilemma. Deze worden opgelost door het terugkerende karakter van vaste overlegvormen: wanneer men elkaar voortdurend opnieuw tegenkomt geeft dit de spelers een reden om elkaars vertrouwen niet te willen schaden. Het vertrouwen tussen de deelnemers (lees: sociale partners) wordt dus groter als men weet dat de onderhandelingen permanent blijven plaatsvinden. Hierdoor wordt ook de geschiedenis in de theorie 'ingebracht', want dankzij de ervaringen uit het verleden kan een institutionele structuur stabiel worden. Enerzijds vormt de geschiedenis de omgeving waarin de onderneming of werknemer zich bevindt, anderzijds zorgt die omgeving voor bepaalde gedragspatronen die het verloop van de geschiedenis mede bepalen. ${ }^{17}$

Als voorbeeld kan dienen de reactie op een externe prijsschok of op appreciatie van de wisselkoers: in Engeland, een LM E, hebben prijsschokken in het verleden op korte termijn geleid tot prijsstijgingen omdat de bedrijven hun winstgevendheid niet in gevaar wilden brengen. In Duitsland daarentegen, een CM E, accepteerden ondernemingen een lagere winstmarge en hielden hun prijzen gelijk om geen marktaandeel te verliezen, want anders hadden ze personeel moeten ontslaan. CM E's bleken dus in bepaalde opzichten star en inflexibel, maar plukten de vrucht van samenwerking. ${ }^{18}$

Het zelfversterkend effect binnen een bepaald type economie gaat zelfs nog verder: bepaalde bedrijven of bepaalde economische activiteiten functioneren beter in een CME, andere in een LME. Een gevolg is bijvoorbeeld dat radicaal nieuwe uitvindingen sneller grootscheeps op de markt gebracht worden in de Verenigde Staten, terwijl in Duitsland het aanbrengen van incrementele verbeteringen in bestaande producten tot de meer winstgevende activiteiten be-

16. Studies naar transactiekosten en principal-agent relationships bevestigen hoe belangrijk dit aspect is. Zie bijvoorbeeld P. Milgrom en J. Roberts, Economics, organisation and management (Englewood Cliffs I992).

17. Hall en Soskice, 'Introduction', I3. Overigens kennen wij dit mechanisme uit de literatuur over het neo-corporatisme.

18. Hall en Soskice, 'Introduction', I6. Het voorbeeld komt uit: M. Knetter, 'Price discrimination by us and German exporters', in: American Economic Review 79:I (I989) I98-210. 
hoort. ${ }^{19}$ De auteurs noemen dit comparative institutional advantages. Dit mechanisme versterkt als het ware het 'profiel' van een bepaald type economie.

Institutional complementarities en comparative institutional advantages, beide gebaseerd op concepten uit de klassieke economische theorie van Ricardo, zorgen voor een mechanisme waarmee micro-economische strategieën worden vertaald naar een macro-economisch systeem. Hiermee krijgt het effect van 'instituties' op het economische proces handen en voeten. Hoewel het verleden een uitdrukkelijke rol speelt, is de indeling tamelijk statisch omdat transformaties binnen het model in feite niet verklaard worden (waarover later meer). De theorie stelt zich ten doel de economie te analyseren vanuit het gezichtspunt van het bedrijfsleven. In dat opzicht leent deze theorie zich voor het generaliseren van de bedrijfsgeschiedenis, die immers dikwijls de geschiedenis van een specifiek bedrijf behandelt. Zo bezien treden Hall en Soskice in de voetsporen van Alfred Chandler, die de schakel legde tussen de bedrijfsgeschiedenis en de betekenis van modern management in de economische ontwikkeling. ${ }^{2 \circ}$

\section{Een taxonomie van markteconomieën}

Uit het principe van de institutionele complementariteit volgt de indeling van de verschillende soorten kapitalistische marktvormen in LME's en CME's. Immers, als de oplossingen van coördinatieproblemen in de thematische clusters elkaar beïnvloeden, zal op grond van de gekozen oplossingen een bepaald type markteconomie ontstaan dat op meerdere terreinen kiest voor 'coördinatie' of juist 'competitie'. Ligt, globaal gesproken, het accent bij alle gekozen oplossingen op concurrentie, kortetermijnwinst, formele juridische contracten en rationeel marktgedrag, dan herkennen we duidelijk de LM E. ${ }^{2 \mathrm{I}}$ Ligt het accent eerder op samenwerking, vertrouwen, afspraken maken, het dienen van het algemeen belang en het nemen van collectieve verantwoordelijkheid, dan spreken we van een CM E. Hoewel er in het model veel aandacht is voor de historische evolutie van de instituties die de economie bepalen en sturen, zijn

19. Hall en Soskice, 'Introduction', $36-44$. Bedrijven zoeken deze voordelen ook op: Nissan opende een ontwerpbureau in Californië en ook Duitse farmaceutische bedrijven openden onderzoekslaboratoria in de Verenigde Staten met het oog op radicale innovaties. Maar voor incrementele verbeteringen aan de verbrandingsmotor lokaliseerde General Motors zijn machinefabrieken in Düsseldorf en niet in Spanje of de Verenigde Staten. Ibidem, 57.

20. Alfred D. Chandler, The visible hand. The managerial revolution in American business (Cambridge, MA en Londen I977); Alfred D. Chandler, Scale and scope. The dynamics of managerial capitalism (Cambridge I990).

21. Hall en Soskice spreken over 'arm's length relations and high levels of competition' (p. 9). 
er dus eigenlijk maar twee ideaaltypen (of clusters) van succesvolle markteconomieën.

De globale indeling van de geavanceerde industrielanden is als volgt. De Angelsaksische landen worden getypeerd als L m E: de Verenigde Staten (bijna als ideaaltype), het Verenigd Koninkrijk, Ierland, Canada, Australië en NieuwZeeland. ${ }^{22}$ De meeste continentale Europese landen zijn CME's: Duitsland (vaak aangehaald als ideaaltype), Frankrijk, België, Nederland, Zwitserland, Oostenrijk, Noorwegen, Zweden en Denemarken. Ook Japan en Zuid-Korea, waar sterke banden bestaan tussen de staat en de economie, worden door Hall en Soskice tot de C M E's gerekend. ${ }^{23}$ De grote omvang van deze zeer gevarieerde groep geeft meteen al aan dat de varieties of capitalism-theorie eerder het beginpunt dan het eindpunt is van de analyse van institutionele verschillen. De landen in zuidelijk Europa (Spanje, Italië, Portugal, Griekenland, Turkije) worden, hoewel redelijk sterk gecoördineerd, toch als een aparte categorie beschouwd, omdat ze een omvangrijke agrarische sector hebben. Bovendien hadden deze landen in het recente verleden een overheidsgestuurde economie, waardoor bedrijfsfinanciering een gecoördineerd karakter kreeg terwijl de arbeidsverhoudingen in deze landen juist geliberaliseerd zijn. ${ }^{24}$

\section{Andere classificaties van markteconomieën}

De classificatie van de varieties of capitalism-theorie vertoont opvallende overeenkomsten met een bekende indeling op basis van geheel andere criteria, namelijk de clustering van $\mathrm{G}$. Esping-Andersen van types verzorgingsstaten. Esping-Andersen kijkt naar de omvang en de organisatie van de verzorgingsstaat en deelt verzorgingsstaten in in liberale, corporatistische en sociaaldemocratische regimes, waarbij de eerste groep de LME's omvat en de laatste twee samen de CM E's vormen. ${ }^{25}$ De overeenkomst tussen de twee indelingen is niet zo heel verwonderlijk, omdat de verzorgingsstaat en het type overlegstructuur waaruit deze ontstaat een grote invloed hebben op het ondernemings-

22. Opmerkelijk is dat China, economische grootmacht in opkomst, door Hall en Soskice nergens wordt genoemd. De meeste comparative capitalism-studies richten zich op o Eso-landen. 23. Er is uitgebreide literatuur over de specifieke kenmerken van het 'Japanse model' tegenover de westerse economieën, die grotendeels wordt genegeerd in de varieties of capitalismtheorie. Zie voor een bruikbaar overzicht Robert Gilpin, Global political economy. Understanding the international economic order (Princeton 200I) I48-I95.

24. Hall en Soskice, 'Introduction', 2I.

25. G. Esping-Andersen, The three worlds of welfare capitalism (Cambridge I990); G. EspingAndersen, Social foundations of post-industrial economies (Oxford 2000). De vergelijking is mede van belang omdat de gevolgde onderzoeksmethodologie overeenkomt. Zie: Bernhard Ebbinghaus en Philip Manow (eds.), Comparing welfare capitalism. Social policy and political economy in Europe, Japan, and the USA (Londen en New York 200I). 
klimaat: denk bijvoorbeeld aan subsidies voor scholing of innovatief onderzoek, of het bestaan van een centraal overlegplatform waarin sociale wetgeving wordt besproken, wat direct effect heeft op de arbeidsverhoudingen.

Het ééndimensionale karakter van een indeling in meer of minder liberale of gecoördineerde markteconomieën is analytisch niet zo heel bevredigend. Immers, men vermoedt al snel dat meerdere criteria zullen leiden tot meerdere vruchtbare combinaties of kenmerkende 'profielen'. In feite wordt dit door Hall and Soskice al aangegeven doordat ze melding maken van een 'mediterrane' variant. Als de vijf institutionele deelgebieden vrijelijk konden variëren, zouden er $2^{5}=32$ verschillende ideaaltypen zijn. Ook al wordt dit aantal door het optreden van institutional complementarities sterk verminderd, toch is aannemelijk dat er meer dan twee succesvolle ideaaltypen zijn.

In de politicologische literatuur die zich bezighoudt met comparative capitalism komen dan ook allerlei classificaties van landen voor. ${ }^{26} \mathrm{Ik}$ zal er hier twee kort behandelen: de reguleringstheorie en de business systems-theorie. De reguleringstheorie (RT: Regulation Theory, soms TR: Theorie de la Régulation) kan als een directe rivaal van varieties of capitalism worden opgevat. Deze theorie is de afgelopen decennia ontwikkeld door een groep Parijse onderzoekers. ${ }^{27}$ Het accent wordt gelegd op de effecten van regulering van de markt, met nadruk op de ontwikkeling van wetenschappelijke specialisaties, het ontstaan van innovaties en de gevolgen voor internationale concurrentie, om vanuit deze factoren economische groei te verklaren (niet voor niets is deze theorie afkomstig uit Frankrijk waar het staatsdirigisme een grote rol speelt). De reguleringstheorie bestrijdt dat een tweedeling voldoende houvast geeft. Zo stelt Boyer: 'From a regulationist perspective, it is difficult to accept that the dichotomy of two polarized models can account for an entire distribution of modern economies' ${ }^{28}$ In een concurrerende classificatie komt deze groep onderzoekers tot een indeling in vier types markteconomieën:

(a) de marktgerichte economie waarin snelle aanpassing prioriteit heeft (hierin vallen de LME's);

26. Een overzicht van theorieën wordt gegeven in Hall en Soskice, 'Introduction', 2-3. Zij onderscheiden drie clusters: modernization approach, neo-corporatism, en social systems of production, waaronder ook de Franse reguleringstheorie valt.

27. Robert Boyer, 'How and why capitalisms differ', in: Economy and society 34:4 (2005) 509-557; zie ook Amable, 'Institutional complementarity and diversity of social systems'. Het betreft een onderzoeksgroep aan het CE PREMAP (Centre pour la recherche economique et ses applications) te Parijs. De RT, soms omschreven als meer een onderzoeksbenadering dan een coherent theoretisch systeem, stamt uit het midden van de jaren zeventig en heeft Marxistische wortels. Zie ook: Bob Jessop (ed.), Regulation Theory and the crisis of capitalism (Cheltenham 200I).

28. Boyer, 'How and why capitalisms differ', 529. 
(b) de meso-corporatistische markteconomie waarin industriële conglomeraten een belangrijke coördinerende rol spelen en het gemeenschappelijk belang voorop staat van degenen die in deze conglomeraten werkzaam zijn (Japan en Korea);

(c) de dirigistische of publieke markteconomie waarin zorgvuldig geregisseerd overheidsingrijpen plaatsvindt (sommige lidstaten van de Europese Unie, vooral Frankrijk);

(d) de sociaal-democratische markteconomie waarin aan sociale rechtvaardigheid en gedeelde welvaart relatief veel belang wordt gehecht (de Scandinavische landen).

De reguleringstheorie kijkt nadrukkelijk naar de evolutie van verschillende vormen van het kapitalisme (op basis van de institutionele kenmerken), en stelt dat de wereldwijd geobserveerde varianten van het kapitalisme empirisch te herleiden zijn tot deze vier clusters. ${ }^{29}$ Er wordt gekeken naar enkele specifieke institutionele deelgebieden zoals het loon-arbeidsmarkt vraagstuk, de rol van de staat, het 'monetaire regime' (de wijze waarop bedrijven gefinancierd worden), de internationale verhoudingen en de mate van competitie binnen het systeem. Ook is er aandacht voor de snelheid van technologische veranderingen, de aard van de effectieve vraag (loongestuurd of winstgestuurd) en de aard van concurrentiekracht (op basis van prijs of op basis van kwaliteit/innovatie). ${ }^{30}$ Ondanks deze nuttige invalshoeken is de reguleringstheorie moeilijk te hanteren. De criteria en hun onderlinge samenhang zijn tamelijk onduidelijk geformuleerd en lijken op het eerste gezicht minder goed toepasbaar, hoewel ze wel recht doen aan de complexiteit van de moderne economie.

In de uiteindelijke vierdeling zien wij de kenmerken waar Hall en Soskice de aandacht op vestigen allemaal terug. ${ }^{3 \mathrm{I}}$ Verder valt op dat de classificatie, op de toevoeging van een aparte categorie die geïnspireerd lijkt door Japan en Zuid-Korea na, dezelfde is als de landenindeling van Esping-Andersen, zij het dan nu gebaseerd op de institutionele kenmerken die het economisch leven reguleren.

Ook de business systems-theorie van Whitley richt zich op de wijze waarop bedrijven hun gedrag moeten afstemmen op de institutionele omgeving. De business systems-theorie probeert aan de hand van een reeks criteria de werking

\footnotetext{
29. Deze classificatie is ontstaan uit de studie van de Amerikaanse en de Franse variant van het Fordism (de term slaat op grootschalige lopende-band productie volgens het arbeidsdeling-principe van het Taylorisme, die leidde tot massaconsumptie en een belangrijk aandeel op de arbeidsmarkt van de middelhoog opgeleide beroepsbevolking). Terwijl varieties of capitalism zich liet inspireren door Duitsland als tegenpool van de Verenigde Staten, is hier dus Frankrijk een belangrijk voorbeeld van een alternatief kapitalistisch model.

30. Boyer, 'How and why capitalisms differ', 521.

31. Ibidem 530-532 voor een overzicht van de kenmerken van deze varianten.
} 
van verschillende types macro-economieën te doorgronden en te kijken hoe de productiefactoren reageren op institutionele invloeden..$^{32}$ Behalve aan de wijze waarop economische activiteiten worden gecoördineerd en gecontroleerd, wordt hier uitvoerige aandacht besteed aan hiërarchie en autoriteit in bedrijfsbestuur. ${ }^{33}$

Evenals bij varieties of capitalism wordt gekeken naar onderwerpen als corporate governance, kapitaalverstrekking (de rol van de kapitaalmarkt) en de mate van coördinatie binnen bedrijven en tussen bedrijven onderling. Ook is belangrijk de wijze waarop werknemers worden gecontroleerd, gemotiveerd en opgeleid, en bij de bedrijfsvoering worden betrokken. Whitley richt zijn aandacht sterker op de culturele inbedding van het individuele bedrijf door het opstellen van criteria die gezamenlijk het nationale business system karakteriseren. Hij is daarmee minder gericht op de analyse van het functioneren van de gehele macro-economie en meer op de kenmerken van individuele bedrijven. De criteria voor specifieke business systems zoals opgesteld door Whitley zijn ingedeeld in drie clusters:

(I) aard van het bedrijf (bijvoorbeeld de hiërarchie in de managementcultuur); (2) marktorganisatie (bijvoorbeeld de mate van samenwerking tussen bedrijven);

(3) autoriteit en controle (hieronder valt ook de wijze waarop werknemers bij de onderneming worden betrokken). ${ }^{34}$

Uit deze maatstaven komt naar voren dat de business systems-theorie zich richt op het functioneren van de onderneming in zijn cultureel-maatschappelijke omgeving (een micro-economisch perspectief), terwijl de varieties of capitalismtheorie en de reguleringstheorie de macro-economie onder de loep te nemen, zij het weliswaar aan de hand van het gedrag van ondernemingen. Alledrie concentreren zij zich op het verband tussen het gedrag van bedrijven en de institutionele omgeving waarin zij zich bevinden.

Ook gaan deze theorieën uit van een bepaalde mate van homogeniteit van het bedrijfsleven binnen een land (of althans van een essentiële verzameling gemeenschappelijke kenmerken) en van een eenduidig te omschrijven 'institutionele setting' waarin de bedrijven opereren. De vraag die hier opkomt, is in hoeverre er verschillende soorten bedrijven in een land zijn die verschillende

32. Deze theorie wordt gehanteerd als theoretisch kader en inspiratiebron voor de onderzoeksgroep в в Nт (Bedrijfsleven in Nederland in de Twintigste Eeuw) (zie www.bintproject.nl (I6 februari 2006)). Richard Whitley, Divergent capitalisms. The social structuring and change of business systems (Oxford 2000).

33. R. Whitley, 'Societies, firms and markets: the social structuring of business systems', in: R. Whitley (ed.), European business systems. Firms and markets in their national contexts (Londen i992) 5-45.

34. Whitley, 'Societies, firms and markets', 8-I9. 
belangen en voorkeuren hebben. Hoewel multinationals een andere opstelling zullen hebben dan het midden- en kleinbedrijf, stellen de onderzoekers toch telkens dat er een nationale institutionele 'cultuur' is, waarin bedrijven zich bewegen.

\section{Nederland gecoördineerd maar ook een beetje liberaal}

Hoewel landen worden geclassificeerd als óf CM E óf LM E, stellen Hall en Soskice dat hun criteria een as opleveren waarop elke economie kan worden gepositioneerd. Dat betekent dat de tweedeling voornamelijk conceptueel van aard is en dat ze erkennen dat er in werkelijkheid allerlei mengvormen optreden. Waar staat Nederland in het spectrum van Hall en Soskice?

Wij zullen eerst bekijken hoe op basis van statistische indicatoren Nederland wordt ingedeeld ten opzichte van andere landen. Vervolgens zal ik op meer kwalitatieve gronden de Nederlandse situatie in de vijf verschillende institutionele deelgebieden van de varieties of capitalism-theorie onder de loep nemen.

Met Daniel W. Gingerich maakte Peter Hall een empirische toetsing van de varieties of capitalism-theorie, door van twintig landen de coördinatiekenmerken in kaart te brengen. Zij construeerden zes samengestelde indicatoren op basis van gepubliceerde statistieken en onderzoeksliteratuur. ${ }^{35}$ Onderscheiden worden: (I) aandeelhoudersmacht; (2) spreiding van macht; (3) omvang van de aandelenmarkt; (4) wijze van looncoördinatie, bijvoorbeeld landelijk of per sector of op bedrijfsniveau; (5) mate van looncoördinatie; en (6) arbeidsmarktmutaties (als percentage van werknemers dat zijn of haar baan minder dan één jaar heeft). Deze gegevens hebben betrekking op de periode I990I995 en zijn dus gericht op een recente, korte periode. Hall en Gingerich stelden een totaalscore op van de coördinatiegraad in elk land en berekenden ook correlatie-coëfficiënten tussen de institutionele deelgebieden om daarmee institutionele complementariteit te bewijzen.

In deze exercitie krijgt Nederland een totaalscore van o, 66 die een redelijke mate van coördinatie impliceert, zij het dat de afstand tot de score van Duitsland $(0,95)$ nog tamelijk groot is (waarbij men moet bedenken dat Duitsland in de theorie de ideaaltypische CM $\mathrm{E}$ benadert). Nederland ligt in ieder geval flink ver af van de score van de Verenigde Staten (०) en Engeland $(0,07)$, de typische LME's (tabel I).

35. Peter A. Hall en Daniel W. Gingerich, 'Varieties of capitalism and institutional complementarities in the macroeconomy: an empirical analysis', paper gepresenteerd op de Annual Meeting of the American Political Science Association, San Francisco 200I, tabel 2. Zie ook p. 6. Een herziene versie van dit artikel (uitgave Discussion Papers van het Max Planck Institut für Gesellschaftsforchung, Keulen, 2004) is te vinden op: http://www.mpi-fg-koeln.mpg. de/pu/abstracts/dpo4-5.html (I6 februari 2006). 
TAв E 1 Verschillende indexcijfers voor de mate van coördinatie

\begin{tabular}{|c|c|c|c|}
\hline & $\begin{array}{l}\text { Coördinatie index } \\
\text { Hall \& Gingerich } \\
\text { (schaal o-1) }\end{array}$ & $\begin{array}{l}\text { Corporatisme index } \\
\text { Hicks-Kenworthy } \\
\text { (schaal o-1) }\end{array}$ & $\begin{array}{c}\text { Siaroff's samenvattende } \\
\text { corp. score } \\
\text { (schaal o-5) }\end{array}$ \\
\hline Duitsland & 0,95 & 0,80 & 3,54 \\
\hline Italië & 0,87 & 0,44 & $\mathrm{I}, 48$ \\
\hline België & 0,74 & 0,67 & 2,84 \\
\hline Frankrijk & 0,69 & 0,40 & $\mathrm{I}, 67$ \\
\hline Nederland & 0,66 & 0,58 & 4,00 \\
\hline Engeland & 0,07 & O,IO & $\mathrm{I}, 65$ \\
\hline Verenigde Staten & 0 & 0,02 & $\mathrm{I}, \mathrm{I} 5$ \\
\hline
\end{tabular}

Bron: Hall en Gingerich, 'Varieties of capitalism and institutional complementarities', 6; Alexander Hicks en Lane Kenworthy, 'Cooperation and political economic performance in affluent democratic capitalism', in: American Journal of Sociology I03, 6: 63I-672; A. Siaroff, 'Corporatism in 24 industrial democracies: meaning and measurement', in: European Journal of Political Research 36 (I999) 2: I75-205.

De index van Hall en Gingerich toont dat Nederland ook ten opzichte van Italië en Frankrijk een wat meer 'liberale' markteconomie heeft, hoewel het volgens Hicks en Kenworthy wel een sterkere mate van corporatisme heeft dan deze landen (zie tabel I). ${ }^{36}$ De arbeidsverhoudingen in Nederland zijn sterk op overleg gebaseerd, maar andere aspecten van de Nederlandse economie zijn sterker 'liberaal', vooral de arbeidsmarkt, die in de jaren negentig flexibeler was geworden. Hierop kom ik terug in de volgende paragraaf.

Volgens de corporatisme-index van Hicks en Kenworthy, die is gebaseerd op de arbeidsverhoudingen in de betreffende landen in de jaren tachtig en negentig, is Nederland iets minder corporatistisch dan Duitsland, maar daar zijn niet alle corporatisme-auteurs het over eens. Corporatisme staat meestal voor een staatsgeleid centraal beleidsoverleg met de sociale partners aangaande de arbeidsverhoudingen, maar wordt ook breder gezien als elke vorm van

36. De Hicks-Kenworthy index meet de mate van corporatisme. Alexander Hicks en Lane Kenworthy, 'Cooperation and political economic performance in affluent democratic capitalism', in: American Journal of Sociology I03, 6: 63I-672. Tevens: Alexander Hicks en Lane Kenworthy, 'Varieties of welfare capitalism', in: Socio-Economic Review I (2003) 27-6r. Zie ook Coen Teulings en Joop Hartog, Corporatism or competition? An international comparison of labour market structures and their impact on wage formation (Cambridge I998). Soortgelijke exercities kan men terugvinden in N.P. Vergunst, The institutional dynamics of consensus and conflict. Proefschrift vu (Amsterdam 2004). Zie voor een recente studie over corporatisme ook Jaap Woldendorp, The polder model: from disease to miracle? Dutch neo-corporatism 19652000 (Amsterdam 2005). Aanknopingspunten voor de kwantitatieve vergelijking van het $\mathrm{Ne}$ derlandse (verzorgingsstaat-)regime zijn te vinden in J.M. Wildeboer Schut, J.C. Vrooman en P.T. de Beer, De maat van de verzorgingsstaat (Den Haag 2000). Tevens verschenen in het Engels: On worlds of welfare. Institutions and their effects in eleven welfare states. Te downloaden op http://www.scp.nl/english/publications/books/9037700497.shtml (I6 februari 2006). 
geïnstitutionaliseerde samenwerking tussen overheid en sociale partners (met name) op het gebied van lonen en arbeidsvoorwaarden. De verschillen tussen de uitkomsten van de studies zijn het gevolg van de combinatie van variabelen die de auteurs hanteren om coördinatie of corporatisme in beeld te brengen.

Wellicht gedreven door het gevoel dat door te variëren in wegingsfactoren en indicatoren er eindeloos veel indelingen gegenereerd kunnen worden, vergeleek Siaroff 23 verschillende corporatisme-rangordes met elkaar in een poging hieruit de grootste gemene deler te distilleren. ${ }^{37}$ In zijn totaalscore is Nederland beduidend corporatistischer dan Duitsland (tabel I); het heeft alleen Oostenrijk, Noorwegen en Zweden boven zich. ${ }^{38}$ Het is duidelijk dat metingen dikwijls verschillende resultaten opleveren. Hierdoor lijken classificatie-exercities niet altijd even nuttig. Voor historisch onderzoek is het achterliggende mechanisme des te interessanter: het gaat dan immers om de drijfveren van actoren om te komen tot bepaalde afspraken of arrangementen. De classificaties helpen om de mogelijke uitkomsten te inventariseren die het resultaat zijn van overleg of conflict.

Zo levert vergelijking van de verschillende maatstaven het inzicht op dat het corporatistische en consensus minnende Nederland in de laatste twee decennia van de twintigste eeuw in twee aspecten door Duitsland wordt voorbijgestreefd: in de mate van consensus en in de mate waarin vakbonden en werkgevers hun loononderhandelingen coördineren. ${ }^{39}$ Katzenstein heeft reeds opgemerkt dat in Nederland binnen de corporatistische structuren meer competitie plaatsvindt. Hij stelt dat in Nederland (en België en Zwitserland) een 'liberaal corporatisme' wordt aangetroffen en zet dit af tegen een 'sociaal corporatisme' in Oostenrijk, Noorwegen en Zweden. ${ }^{40}$

Wij kunnen dus concluderen dat Nederland in internationaal comparatief opzicht een CM E is met een aantal liberale kenmerken. Omdat de varieties of capitalism-theorie vergeleken met de meeste corporatisme-varianten ook zaken als aandeelhoudersmacht, de omvang van de aandelenmarkt, en de aard van interactie tussen publiek en privaat (denk ook aan de mate van staatsdirigisme zoals in Frankrijk) meeweegt, schuift Nederland op in de richting van een LME.

37. A. Siaroff, 'Corporatism in 24 industrial democracies: meaning and measurement', in: European Journal of Political Research 36:2 (I999) I75-205.

38. Siaroff introduceert het concept 'integration' in plaats van 'corporatisme'. Dit ligt dichter bij het Hall-Soskice-concept van coördinatie en hierin staat Duitsland in de rangordes vanaf de jaren zeventig wél boven Nederland. Siaroff meet 'integration' voor vier na-oorlogse tijdvakken en signaleert dat Nederland opschuift in de richting van een 'pluralist economy', hetgeen zijn term is voor een LME.

39. Ibidem, Tabel I-3, I80-I8I, I83-I85.

40. Katzenstein, Small states in world markets, I24-I25. Het betreft een iets eerdere periode. 


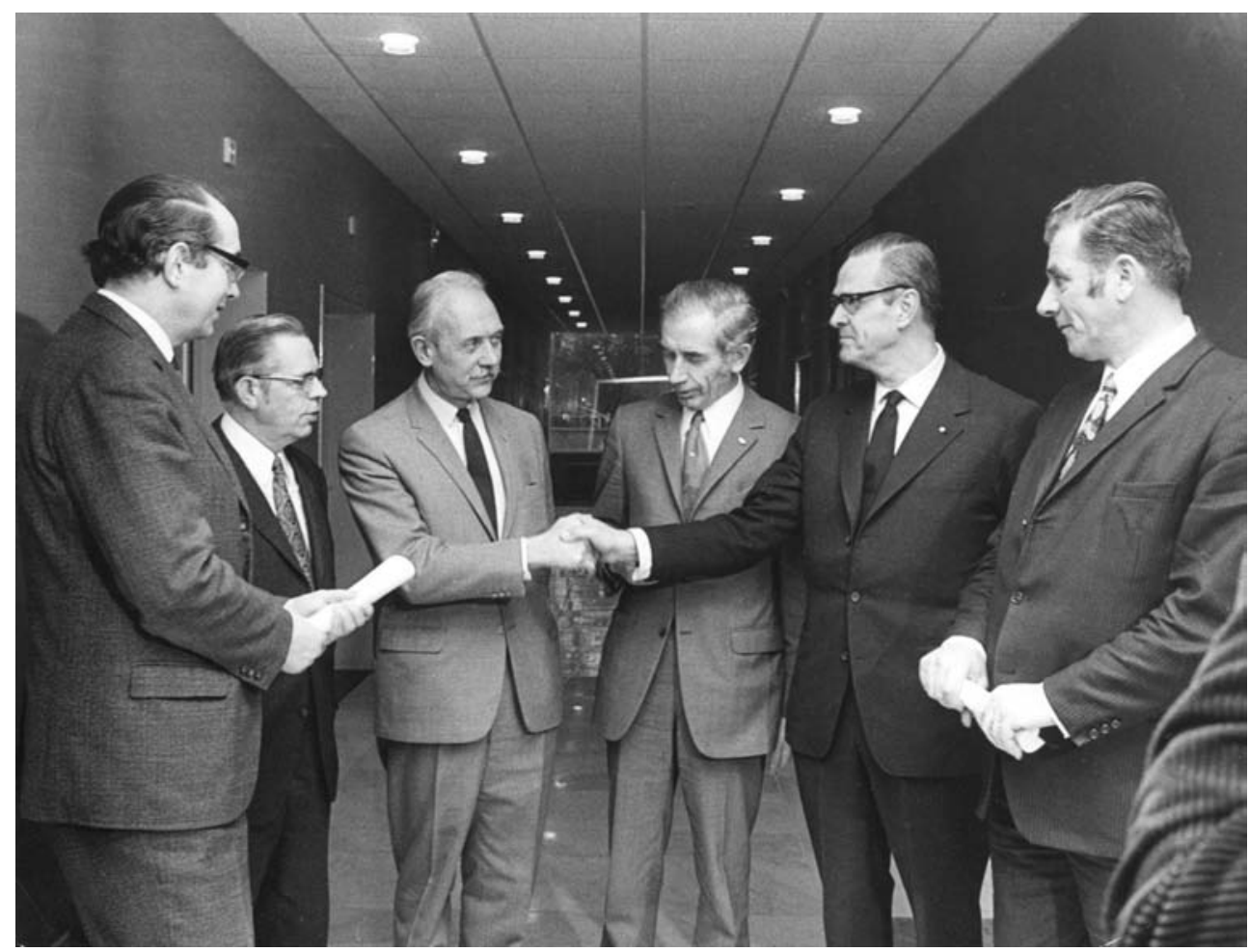

(wrs.) 1 maart 1972. Einde conflict in de metaal. Vlnr: Arie Groeneveld (Ind. Bond NVV), Piet Brussel (Ind. Bond NKV), R. Erdbrink (bemiddelaar), H. van Dijk (Ind. Bond CNV), A. Prins (FME), L. Laurier (Unie B HLP) (Fotobureau Stokvis, Collectie IISG B13/742, met dank aan Gemeentearchief Den Haag).

\section{De Nederlandse variety of capitalism}

In bovenstaande rangordes worden de kenmerken van institutionele deelgebieden uitgedrukt in een indexcijfer. Deze worden dan samengevoegd tot een samengesteld indexcijfer dat iets zegt over de economie in zijn geheel. Het ligt voor de hand om een meer kwalitatief inzicht te wensen. Hoe zit het met de coördinatiegraad in Nederland in de specifieke deelgebieden van Hall en Soskice, en welke veranderingen treden daarin op? Deze paragraaf gaat in op de ontwikkelingen binnen Nederland. Ik zal daarbij geen cijfermatige indicatoren opstellen maar een globale beschrijving geven van de kenmerkende ontwikkelingen in de verschillende deelgebieden. De internationale vergelijking wordt daarmee verlaten. We zullen onderzoeken of in de deelgebieden de ontwikkelingen gelijk opgaan, zoals door de theorie van institutionele complementariteit wordt verondersteld.

Allereerst kunnen we vaststellen dat de Nederlandse economie met zijn traditie van overleg, consensus, veelvuldige kartelvorming en (de afgelopen de- 
cennia) uitgebreide collectieve voorzieningen, voor het grootste deel van de twintigste eeuw een с м E kan worden genoemd. Dit wordt niet alleen duidelijk op basis van het corporatisme in de arbeidsverhoudingen, maar ook na bestudering van de geschiedenis van het Nederlandse bedrijfsleven. ${ }^{4 \mathrm{I}}$

Overleg past naadloos in een oude Nederlandse traditie, die samenhangt met het proces van verzuiling en haar wortels heeft in het zeventiende-eeuwse ontstaan van een burgerlijke natie, hetgeen vanuit allerlei invalshoeken is bestudeerd..$^{42}$ Het heeft geleid tot een omvangrijke literatuur over (neo)corporatisme, het consensusmodel en de overlegeconomie. ${ }^{43}$

Beschouwen we de economische ontwikkeling, dan valt een interessante golfbeweging waar te nemen tussen de polen 'liberaal' en 'gecoördineerd'. Vanaf het midden van de negentiende eeuw kunnen we spreken van een tendens in de richting van liberalisering van de economie, die rond I9I4 eindigt. Na de crisis van de jaren dertig en de Tweede Wereldoorlog kwam er na I945 juist een sterke ontwikkeling van institutionele vernieuwing en coördinerend overheidsbeleid op gang. Initiatieven als de Wet op de Publiekrechtelijke Bedrijfsorganisatie (Рво) en het industrialisatiebeleid hebben niet in alle opzichten hun doel bereikt, maar hebben wel de architectuur van de Nederlandse economie ingrijpend beïnvloed. Daar kwam bij dat de opkomst van de verzorgingsstaat een grote impact had op de economie, zowel door de sociale zekerheidswetgeving en het ondersteunen van de effectieve vraag, als door de toenemende belastingdruk voor bedrijfsleven en consumenten.

Vanaf het begin van de jaren tachtig was het macro-economische beleid sterk gericht op privatisering en deregulering van de economie, alsmede op flexibilisering van de arbeidsmarkt. Opvallend is dat deze 'neoliberale hervormingen' waren ingebed in de bestaande, op consensus gerichte institutionele omgeving. $^{44}$

De liberale kenmerken van de Nederlandse economie hangen samen met de eigenschappen van een kleine, open economie. Hierbij speelt de Europese integratie natuurlijk een belangrijke rol, vooral de realisatie van een gemeen-

41. Sluyterman typeert Nederland als een см E die zich de afgelopen decennia heeft ontwikkeld in de richting van een LME. Sluyterman, Kerende kansen, 324.

42. Sommigen stellen dat consensus en overleg al ten tijde van de Republiek een prominente plaats in de Nederlandse samenleving hadden. Zie bijvoorbeeld Willem Frijhoff en Marijke Spies, 1650. Bevochten eendracht (Den Haag I999). Een sociologische studie over vergaderen in Nederland in langetermijnperspectief is: Wilbert van Vree, Nederland als vergaderland. Opkomst en verbreiding van een vergaderregime (Groningen I994).

43. Doreen Arnoldus, Karel Davids, Gregory Vercauteren en Ivan Wijnens, 'De groei van de overlegeconomie in Nederland en België', in: Tijdschrift voor Sociale en Economische Geschiedenis (verder TSEG) I (2004) nr.I 76-I09, aldaar 80-93.

44. J.L. van Zanden, Een klein land in de $20 e$ eeuw. Economische geschiedenis van Nederland 1914-1995 (Utrecht 1997) 244. 
schappelijke markt. ${ }^{45}$ Ook de wereldwijde tendens vanaf de jaren tachtig om restricties op internationaal kapitaalverkeer op te heffen heeft vooral in open economieën de noodzaak doen voelen tot een (neo)liberaal beleid en aandacht voor internationale concurrentiekracht. ${ }^{46}$ Zo zien we dat aan het eind van de twintigste eeuw de Nederlandse economie weer een aantal liberale kenmerken heeft gekregen, hoewel er tegelijkertijd toch nog steeds een verregaande graad van coördinatie is.

Beter inzicht in dit proces wordt bereikt door te kijken hoe de Nederlandse economie zich gedraagt in de vijf verschillende institutionele deelgebieden van Hall en Soskice. Omdat het omvangrijke themagebieden betreft, zal ik hier slechts enkele globale ontwikkelingen per deelgebied aanstippen.

\section{Arbeidsverhoudingen}

In de Nederlandse economie is sinds de oprichting van de Stichting van de Arbeid in I945 en de р во in I950 (met de oprichting van de Sociaal-Economische Raad, de SER), het overleg tussen werkgevers, vakbonden en overheid sterk geïnstitutionaliseerd. ${ }^{47}$ Dit had zijn wortels in de jaren twintig met de Hoge Raad van Arbeid. ${ }^{48}$ De onderhandelingen over lonen en arbeidsomstandigheden spelen zich op centraal niveau af bij de Stichting van de Arbeid, maar ook allerlei onderwerpen die besproken worden in de s E R spelen een rol in de arbeidsverhoudingen. ${ }^{49}$ Op bedrijfstakniveau wordt er onderhandeld over collectieve arbeidsovereenkomsten (CAO's), waarbij een groot deel van de bedrijven zich aansluiten.

De vakbonden hebben aanvankelijk, in de periode van naoorlogs herstel, actief geparticipeerd in het overleg..$^{\circ}$ In de periode van circa 1960-1982 was sprake van polarisatie die leidde tot gebrek aan overeenstemming. Dit viel samen met het einde van de geleide loonpolitiek. De vakbonden zetten in op loonsverhoging als aandeel in de winst, het aantal stakingen nam toe, en vanaf de jaren zeventig kwam daarbij ook de politieke polarisatiestrategie van de PvdA, die voor een verminderde politieke consensus in de politiek zorgde. Bij

45. Met name de Single European Act uit I986 vormde het startschot voor de verwezenlijking van een vrije interne markt voor goederen en kapitaal.

46. Sluyterman wijst in dit verband ook op de constante stroom managementideeën die sinds de Marshallhulp uit de Verenigde Staten is geïmporteerd, maar concludeert dat het moeilijk te bepalen is in welke mate deze een daadwerkelijke impact hebben gehad op het Nederlandse bedrijfsleven. Sluyterman, Kerende kansen, I9I-I96, 323.

47. Arnoldus e.a., 'De groei van de overlegeconomie,' 96.

48. Coen Helderman, 'De Hoge Raad van Arbeid, I9I9-I940(-I950)', in: TSEG I (2004) nr. 2 45-70. Zie ook Sluyterman, Kerende kansen, I74. Van Zanden, Een klein land, II2, I82.

49. Zo publiceerde de SER bijvoorbeeld ook adviezen over medezeggenschap en de structuurregeling van NV's en Bv's.

50. Van Zanden, Een klein land, I05, II3-II6. 
de structurele problemen in de economie in de vroege jaren tachtig keerde de bereidheid tot overleg en compromis echter weer terug..$^{{ }^{\mathrm{I}}}$

Het aanbodzijdebeleid dat in de jaren tachtig in de plaats kwam van het Keynesianisme, leidde tot een herstel van de waardering voor de ondernemingen, die daarmee ook meer zeggenschap over de arbeidsverhoudingen naar zich toetrokken. Deze 'kantelende arbeidsverhoudingen' leidden echter niet tot een verschraling van het overleg, maar juist tot een verbreding van de invloed van CAO's. ${ }^{2}$ Hierin is wel een tendens waar te nemen van decentralisatie naar bedrijfstakniveau.

De trend naar decentraal loonoverleg vinden we, nog sterker dan in het Akkoord van Wassenaar uit I982, terug in het Centraal Akkoord "Een nieuwe koers", dat op 4 november I993 werd gesloten in de Stichting van de Arbeid. Het doel om werkgelegenheid te scheppen door loonmatiging werd in dit akkoord alleen globaal vastgelegd en moest op bedrijfstakniveau worden uitgewerkt. ${ }^{53}$ De varieties of capitalism-theorie stelt dat centraal én decentraal overleg noodzakelijk is voor een hoge mate van coördinatie in een economie, omdat controle op het naleven van afspraken op meerdere niveaus moet kunnen plaatsvinden.

Een blijvend kenmerk van het Nederlandse bedrijfsleven in de twintigste eeuw was derhalve de hoge organisatiegraad van de arbeidsverhoudingen: zowel bedrijven als werknemers waren gedurende vrijwel de hele twintigste eeuw verenigd in centrale verbonden, zodat individuele ondernemers het overleg over collectieve voorzieningen konden delegeren en het overleg in de praktijk niet al te veel door kortetermijnbelangen werd doorkruist. Hoewel de jaren zestig en zeventig een relatief sterk gepolariseerd karakter hadden en het overleg toen dikwijls niet tot consensus leidde, bleef er toch een uitgebreide institutionele structuur intact die kenmerkend is voor een CM E. De arbeidsverhoudingen kunnen tamelijk rustig genoemd worden, vooral in internationaal opzicht. $^{54}$

Vanaf het midden van de jaren tachtig heeft zich een aantal ingrijpende veranderingen voltrokken op de arbeidsmarkt, waardoor deze flexibeler en liberaler is geworden. Deze hervormingen, die zich afspeelden in de drie beleids-

51. H. de Liagre Böhl, 'Consensus en polarisatie. Spanningen in de verzorgingsstaat, I945I990', in: Remieg Aerts, Herman de Liagre Böhl, Piet de Rooy en Henk te Velde, Land van kleine gebaren. Een politieke geschiedenis van Nederland 1780-1990 (Nijmegen I999) 265-314, aldaar 29I-29I, 3I6-3I8. Zie ook: F.H. Tros, W. Albeda en W.J. Dercksen, Arbeidsverhoudingen in Nederland (Alphen aan den Rijn 20047) 8I-98; Van Zanden, Een klein land, 244.

52. Wout Buitelaar en Jan-Peter van den Toren, Tijd in beweging: de AWVN 1919-1999. Een Werkgeversvereniging in de Nederlandse overlegeconomie (Haarlem I999) 67 .

53. Jan Bruggeman en Aart Camijn, Ondernemers verbonden. 100 jaar centrale ondernemingsorganisatie in Nederland (Wormer I999) 24I.

54. Sjaak van der Velden, Stakingen in Nederland:arbeidersstrijd 1830-1995 (Amsterdam 2000). 
domeinen arbeidsverhoudingen, sociale zekerheid en arbeidsmarktbeleid, zijn uitvoerig geanalyseerd door Visser en Hemerijck. De hervormingen leidden tot een herverdeling van arbeid en een 'miraculeuse' toename van het aantal banen. Het volstaat hier vast te stellen dat dit een aantal 'liberale' kenmerken heeft geïntroduceerd in de arbeidsmarkt. Al kan men stellen dat deze gepaard gingen met typisch 'gecoördineerde' vormen van overleg en consensus (zoals het Akkoord van Wassenaar uit I982 en het akkoord 'Een nieuwe koers' uit 1993), toch is over het geheel arbeid flexibeler en goedkoper geworden. ${ }^{55}$ Het gevolg van deze veranderingen is een beweging in de richting van de LM E.

\section{De mate waarin bedrijven investeren in beroepsopleidingen en bedrijfstrainingen}

Het spreekt voor zich dat onderwijs een belangrijke bijdrage levert aan de arbeidsproductiviteit en daarom van groot belang is voor het functioneren van de economie. In de varieties of capitalism-theorie gaat het echter niet om het algemeen (theoretisch) onderwijs maar om het beroepsonderwijs (vocational training), zowel in de initiële fase als tijdens de loopbaan. Hoe is dit in Nederland georganiseerd en welke invloed oefenden de sociale partners hierop uit? Vinden we hier een bepaalde mate van vertrouwen en collectieve samenwerking, typisch voor een СмE?

Het Nederlandse onderwijs is traditioneel gebaseerd op dagonderwijs, maar een belangrijke uitzondering vormt het 'leerlingwezen', dat opkwam in de jaren vijftig en dat werk en scholing combineert. Het initiële beroepsonderwijs bestaat in Nederland uit een theoretische en een beroepsgerichte leerweg in het vм во (sinds 200I, ontstaan uit vво еп маvо), en verder uit het м во en нво (en deels wo). In deze schooltypes is evenals in het leerlingwezen het 'duale leren' een belangrijk kenmerk: leerlingen zijn in dienst van een bedrijf en gaan enkele dagen per week naar school. ${ }^{56}$ Een dergelijk systeem was van oudsher in Duitsland en Oostenrijk (typische см E's) dominant, maar in Engeland was duaal leren juist veel minder belangrijk. ${ }^{57}$ In Nederland heeft het leerlingwezen een belangrijke impuls gekregen door de eerste Industrialisatienota van J.R.M.van den Brink uit I949, waarin het duale leren als de drager van de vakopleiding werd beschouwd. Eind jaren zestig werd het leerlingwezen

55. Jelle Visser en Anton Hemerijck, 'Een Nederlands mirakel'. Beleidsleren in de staat (Amsterdam i998).

56. Martine Maes, Beroepsonderwijs en -opleiding in Nederland. Een korte beschrijving CEDEFop: Europees Centrum voor de Ontwikkeling van Beroepsopleiding. Panorama series 97 (Luxemburg 2004) 3I-35, 44-45.

57. H.M. Bronneman-Helmers, L.J. Herweijer en H.M.G. Vogels, Voortgezet onderwijs in de jaren negentig. SCP 2002-3 (Den Haag 2002) 23. 
verzelfstandigd in de Wet op het Leerlingwezen. ${ }^{58}$ Tijdens de economische recessie aan het begin van de jaren tachtig werd opnieuw geprobeerd om het leerlingwezen te stimuleren, met als voorbeeld het duale stelsel in Duitsland. In de jaren negentig werd in het Nederlandse onderwijsbeleid in algemene zin de blik dikwijls op de Angelsaksische wereld gericht - met name in plannen voor marktwerking en de structuur van regionale opleidingscentra voor secundair beroepsonderwijs en volwasseneneducatie. ${ }^{59}$ Tegelijkertijd bleef er in het beroepsonderwijs een aanhoudende aandacht voor duaal leren, ook in de recente periode. ${ }^{60}$

Ook de aandacht voor beroepsopleidingen voor werknemers op latere leeftijd is de afgelopen decennia sterk toegenomen. In Nederland werd in I986 ongeveer drie procent van de totale arbeidstijd aan postinitiële opleidingen besteed. Met name jonge, hoogopgeleide mannen volgden bedrijfsopleidingen. Vrouwen, laagopgeleiden en oudere werknemers namen naar verhouding hieraan weinig deel. Vooral bij de openbare nutsbedrijven, banken en zakelijke dienstverlening werden veel opleidingsactiviteiten ondernomen. In de industrie was de deelname aan bedrijfsopleidingen lager, in de landbouw het laagst. ${ }^{6 r}$ Dit is niet verwonderlijk als men bedenkt dat de voornaamste werkgelegenheidsgroei in de dienstensector plaatsvond en deze sector relatief hoogopgeleide werknemers nodig heeft en zich snel ontwikkelt.

Afspraken over beroepsopleidingen voor werknemers zijn in CAO's vastgelegd. De overheid is hier alleen indirect bij betrokken, de verantwoordelijkheid voor het verschaffen en financieren van scholing ligt bij de werkgeversorganisaties en werknemers. Dit wordt wel 'een onderscheidend kenmerk van de Nederlandse scholing' genoemd. ${ }^{62}$

Sinds de jaren tachtig is op centraal niveau en op bedrijfstakniveau in toenemende mate gehamerd op het belang van scholing en opleiding, opdat Nederland niet achterop zou raken in de meedogenloze competitie van de geliberaliseerde wereldeconomie. De s E R en de Stichting van de Arbeid speelden hierbij een belangrijke rol. ${ }^{6}$ Het bewust bevorderen van 'life long learning' en

\footnotetext{
58. Leon Römkes en Karel Visser, Beroepsonderwijs en scholing in Nederland CE D E Fo P: Europees Centrum voor de Ontwikkeling van Beroepsopleiding (Luxemburg I992) 43-44.

59. Bronneman-Helmers e.a., Voortgezet onderwijs, 25.

6o. In $200 \mathrm{I}$ werd een overeenkomst getekend tussen de sociale partners en het Ministerie van Onderwijs, Cultuur en Wetenschap, over leer-werktrajecten om het leren op de werkplek te versterken in het beroepsonderwijs. In 2003 werd deze bij wet vastgelegd; het gevolg is hernieuwde samenwerking tussen bedrijven, scholen en regionale overheid. Maes, Beroepsonderwijs- en opleiding, 49.

61. Römkes en Visser, Beroepsonderwijs en scholing, 60-61.

62. Maes, Beroepsonderwijs- en opleiding, 39.

63. Zie bijvoorbeeld de omvangrijke reeks SER-adviezen over volwassenenonderwijs en beroepsonderwijs die verscheen tussen 1985 en 2005. Op www.ser.nl (7 maart 2006) is een publicatieoverzicht te vinden.
} 


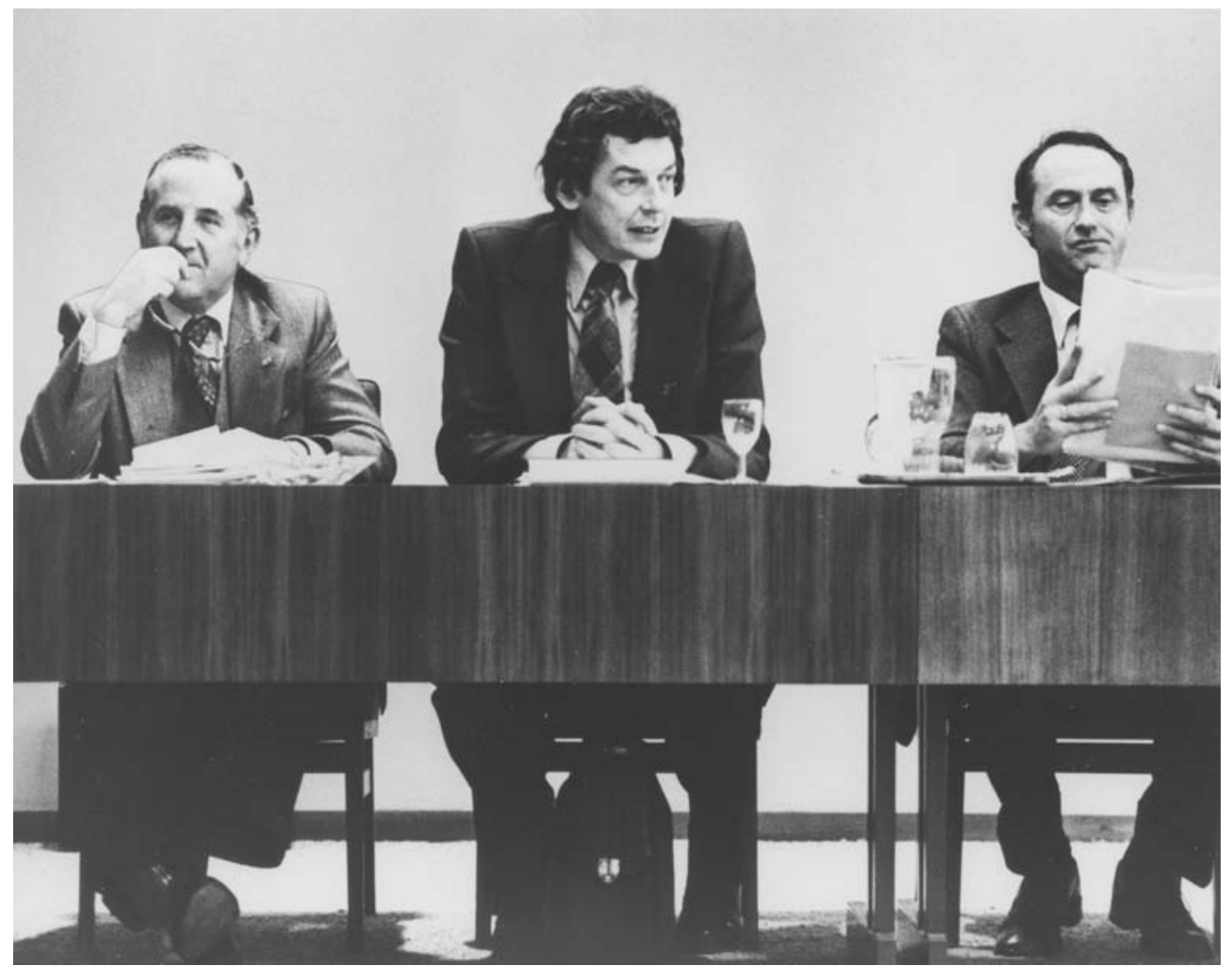

(wrs 1976) De drie partijen in de Nederlandse CME. C. van Veen (werkgevers), W. Kok (werknemers) en de overheid J. Boersma (minister van Sociale Zaken) (Collectie IISG B26/316).

'employability' op centraal en decentraal niveau geeft aan dat oplossingen op dit gebied niet worden overgelaten aan de markt. Vanaf medio jaren negentig is er zowel bij individuele bedrijven als binnen het CAO-overleg aandacht voor 'functionele flexibilisering'. Het aantal deelnemers aan bedrijfsgerelateerde cursussen nam in de jaren negentig in alle leeftijdgroepen toe. ${ }^{64}$

In een dynamische economie heeft een bedrijf voortdurend personeel met nieuwe technologische competenties nodig. Volgens de varieties of capitalismtheorie werft men in de LM E specifiek gekwalificeerd personeel vaker op de arbeidsmarkt, maar stuurt men in een CM E het eigen personeel, dat een vast dienstverband heeft en meestal lange tijd in dienst blijft, op cursus. Nederland heeft een systeem van centraal gereguleerd beroepsonderwijs waarin duaal leren een belangrijke rol speelt. Het duale leren en het investeren in

64. Tros, Albeda en Dercksen, Arbeidsverhoudingen in Nederland, I70-I7I; Frans van Gaal, Spanning in de polder. 55jaar CAO ontwikkeling in de metaal-en elektrotechnische industrie (Apeldoorn 200I) I43-IG3. 
postinitiële opleidingen veronderstellen een bepaalde mate van vertrouwen en betrokkenheid bij het algemeen belang. In de wetgeving en de centrale bipartiete afspraken hieromtrent observeren we tevens de institutionele complementariteit van centrale coördinatie in arbeidsverhoudingen en opleidingsstelsels. In het deelterrein van beroepsopleidingen en trainingen is Nederland sinds de jaren vijftig steeds sterker gaan voldoen aan de kenmerken van een CM E.

\section{De wijze waarop kapitaal wordt aangetrokken en 'corporate governance'}

In bestuurlijk opzicht kennen Nederlandse bedrijven het Rijnlandse bestuursmodel met een Raad van Commissarissen boven een Raad van Bestuur, een constructie die ook in Duitsland, maar niet in de Angelsaksische landen wordt aangetroffen. Vooral het netwerk van invloedrijke personen die diverse commissariaten vervullen, vergroot de mogelijkheid van coördinatie tussen bedrijven. Dit systeem maakt het mogelijk om kapitaalbronnen aan te boren buiten de beurs om, aangezien de commissarissen kunnen bemiddelen en instaan voor de betrouwbaarheid van een bedrijf. Het bestuursmodel in de CME kenmerkt zich door de gecombineerde zeggenschap van managers, commissarissen, aandeelhouders en ondernemingsraad. In de L M E, waar bedrijven afhankelijk zijn van de beurs, hebben de aandeelhouders een sterkere invloed op de koers van een bedrijf.

De ontwikkeling van het bedrijfsleven in Nederland in de twintigste eeuw past in grote lijnen binnen het door Chandler beschreven kader van de opkomst van de managerial firm. ${ }^{65}$ Dit ging in het begin van de twintigste eeuw gepaard met een overgang van dividendbeleid (waarbij de winst werd uitgekeerd) naar reserveringsbeleid (waarbij de winst werd teruggeploegd in de onderneming). Professionele managers kozen voor dit laatste, omdat het een manier bood om groei te realiseren en dus paste bij een langetermijnstrategie.

Chandler maakt een onderscheid tussen ondernemingen waar leiding en eigendom zijn gecombineerd, zoals familiebedrijven, en ondernemingen met een duidelijke scheiding van bestuur en eigendom, zoals veel beursgenoteerde ondernemingen. Het bijzondere van Nederlandse (ex-)familiebedrijven is dat zij lange tijd in staat waren ondanks vermindering van het eigendom na aandelenuitgiftes, toch het bestuur grotendeels in eigen handen te houden. In dit opzicht zijn deze ondernemingen niet 'Chandeleriaans' in de oorspronkelijke betekenis.

65. Van Zanden, Een klein land, 49, 67-72; Sluyterman, Kerende kansen, 270-272. Voor een nuancering en aanvulling van deze stelling, zie: Jacques van Gerwen, Ferry de Goey en Hugo van Driel, 'De Managerial Revolution in de vs en Nederland in de twintigste eeuw', in: TSEG 2 (2005) nr.I 30-58. 
De beschermingsconstructies die ervoor zorgden dat de kapitaalverstrekkers geen bestuurlijke invloed op het bedrijf kregen (bijvoorbeeld door preferente aandelen in handen van de besturende familie te houden) waren in Nederland lange tijd in zwang bij familiebedrijven. Ook bij 'gewone' beursgenoteerde ondernemingen werden aandelenconstructies dikwijls zo ingekleed dat de invloed van de aandeelhouder gering bleef. Tot aan de jaren tachtig was de positie van de aandeelhouders hierdoor tamelijk zwak. ${ }^{66}$ Zo blijkt dat in de CM E de opkomst van de professionele manager niet noodzakelijk leidde tot vergroting van de aandeelhoudersmacht en konden gevestigde belangen en coördinatienetwerken intact blijven.

Door de beschermingsconstructies hoefde het bedrijfsleven tot in de jaren tachtig ook niet bang te zijn voor vijandige overnames. Maar daarna begon de invloed van de aandeelhouders toe te nemen. Dit was het gevolg van een aantal faillissementen door falend management, de toegenomen mobiliteit van het kapitaal die maakte dat geldschieters kieskeuriger konden worden, en de opkomst van grote institutionele beleggers die meer macht konden uitoefenen. Deze toenemende invloed van aandeelhouders heeft het korte termijnbeleid, gericht op aandeelhouderswaarde, versterkt. In het deelterrein van corporate finance lijken in alle CME's de bedrijven in de jaren tachtig en negentig meer kenmerken van de LM E aan te gaan nemen, omdat het aantrekken van beurskapitaal noodzakelijk is voor grootschalige technologische investeringen. Nederland is hierin 'liberaler' dan Duitsland omdat het geen traditie heeft van grote industriebanken.

In dit beleidsterrein hebben de neoliberale hervormingen en de internationalisering van markten veel invloed gehad en vertoont Nederland in toenemende mate kenmerken van een LM E.

\section{Netwerken met andere bedrijven}

In een typische CME zijn er netwerken en samenwerkingsverbanden tussen bedrijven, waarin informatie-uitwisseling of coördinatie en afstemming plaatsvinden, zoals bijvoorbeeld het afspreken van standaarden en het opzetten van gezamenlijke $R \alpha D$-projecten. Ook de inrichting van onderzoeksconsortia waarin innovatie gezamenlijk en met steun van de overheid wordt gestimuleerd, kan gezien worden als een kenmerk van de CмE.

Het bedrijfsleven in Nederland kende al vanaf de jaren dertig kartels en gentlemen's agreements maar de invloed daarvan nam in de naoorlogse decennia af. Hoewel er wel een aantal brancheorganisaties bleef bestaan, is dе р во, die in alle bedrijfstakken invloedrijke brancheorganisaties beoogde op te richten, buiten de agrarische sector grotendeels mislukt. Vanaf de jaren zeventig

66. Sluyterman, Kerende kansen, I98, 270-27I, 3I4; Ad van Iterson en René Olie, 'European business systems: the Dutch case', in: Whitley, European business systems, 98-II6. 
werden fusies en overnames steeds belangrijker. Sluyterman stelt: 'Terwijl nog onderzoek gaande is naar de intensiteit van de kartelvorming in de naoorlogse jaren, is wel al duidelijk dat in de jaren zestig de ondernemers in toenemende mate integratie boven samenwerking verkozen'. ${ }^{67}$ In de jaren tachtig en negentig werd de toegenomen concurrentie dikwijls het hoofd geboden met strategische allianties. Toch wil dit alles uiteraard niet zeggen dat er geen concurrentie was. Ook legde de Europese Unie in toenemende mate richtlijnen op die een vrije markt moesten bevorderen. Terwijl wetgeving van de Europese Unie kartels verbood, werd Nederland medio jaren tachtig nog een 'kartelparadijs' genoemd. Met de verdergaande Europese eenwording werd op naleving van het verbod steeds nauwgezetter toegezien. ${ }^{68}$ Het beeld is dus tamelijk diffuus.

Hall en Soskice zien fusies en overnames als een kenmerk van LM E's, want ze vormen een wijze waarop bedrijven kunnen groeien waarbij gebruik wordt gemaakt van het marktmechanisme. In Nederland zien we echter vrijwillige fusiebereidheid, die (in tegenstelling tot vijandige overnames) moet worden beschouwd als een kenmerk van een CM E, omdat fuseren, evenals kartelvorming, een manier is waarop bedrijven door samen te werken (of samen te gaan) verdere expansie kunnen realiseren. ${ }^{69}$

Actieve overheidsinterventie in de Nederlandse economie was traditioneel al tamelijk gering (vooral vergeleken met bijvoorbeeld de Franse), maar de tendens is om deze verder te verminderen. Overheidsplanning had in Nederland eerder een ondersteunend dan een autoritair karakter: bedrijven werden niet strak gedirigeerd door de staat. Op dit gebied vinden wij toenemende liberale kenmerken in de gecoördineerde Nederlandse economie van de afgelopen decennia. $^{70}$

Heeft de samenstelling van het bedrijfsleven iets te maken met de coördinatiegraad? Het Nederlandse bedrijfsleven wordt gekenmerkt door een relatief groot aantal multinationals (gemeten naar de totale waarde van hun activa), waarvan de bestuurlijke top via raden van commissarissen een netwerk vormt. ${ }^{7 \mathrm{I}}$ Ook zou men kunnen vermoeden dat het grote aantal familiebedrijven een

67. Keetie E. Sluyterman, 'Nederlandse bedrijfsgeschiedenis, de oogst van vijftien jaar', in: NEHA-Jaarboek voor economische, bedrijfs- en techniekgeschiedenis, 62 (I999) 35I-387, aldaar 36r. Zie ook Sluyterman, Kerende kansen, 203-2II.

68. Sluyterman, Kerende kansen, I44-I45, 203-205, 260, 3I4; R.T. Griffiths (met W. Asbeek Brusse), "Paradise lost or paradise regained?" Cartel policy and cartel legislation in the Netherlands', in: S. Martin (ed.) Competition policy in Europe (Amsterdam I998) I5-39.

69. Hall en Soskice, 'Introduction', 24, 27.

70. Ad van Iterson en René Olie, 'European business systems: the Dutch case', in: Whitley, European business systems, 98-II6. Men denke ook aan het industrialisatiebeleid in Nederland in de jaren 1949-1963, dat eerder stimulerend en faciliterend dan dirigistisch was.

71. Van Zanden, Een klein land, 59. 
effect heeft op de coördinatiegraad, bijvoorbeeld in de arbeidsverhoudingen. Sinds de jaren tachtig zijn er allerlei verzelfstandigde voormalige overheidsinstellingen, die zich buiten de markt hebben ontwikkeld maar na verzelfstandiging gedwongen werden onder druk van de vrije markt hun bedrijfscultuur te veranderen. Maar zij zijn voornamelijk actief op de binnenlandse markt. Er wordt wel gesteld dat de concurrentie op de binnenlandse markt minder hevig is dan op de buitenlandse markt. Nader onderzoek naar concurrentie en naar de organisatie van innovatieve projecten is wenselijk om de effecten van deze ontwikkelingen te beschrijven. De varieties of capitalism-theorie is gericht op het analyseren van de institutionele omgeving en stelt dat alle economische spelers hun voordeel doen met de aanwezige institutional complementarities en zich daaraan conformeren. Dit zou kunnen betekenen dat multinationals zich op het internationale vlak anders gedragen dan op de gecoördineerde binnenlandse markt.

Op het gebied van innovatie en technologische ontwikkeling vond, afhankelijk van de bedrijfstak, in meer of mindere mate samenwerking plaats tussen grote en kleinere bedrijven, waarbij bijvoorbeeld onderzoeksconsortia of gezamenlijke laboratoria werden ingericht. De overheid speelde daarbij een belangrijke rol. Voor een systematische internationale vergelijking van samenwerking op het gebied van innovatie is hier geen plaats, maar feit is dat op dit terrein zowel in de LME's als in de CME's samenwerking plaatsvindt. ${ }^{72}$

De Nederlandse economie heeft een 'open karakter'. Op zich maakt dat Nederland nog niet tot een LM E, want het betekent slechts dat het aandeel van import en export in het nationaal inkomen hoog is. Het grote aandeel van de internationale handel betekent wel dat veel bedrijven overeind blijven in de internationale concurrentie op de wereldmarkt. Ook zijn uitgaande en inkomende buitenlandse directe investeringen in de jaren tachtig en negentig sterk toegenomen. Men zou kunnen spreken van een Nederlandse paradox van een internationaal gerichte economie en een beschermde binnenlandse markt, want zoals we hierboven zagen, is de binnenlandse markt in Nederland relatief gecoördineerd en is er veel samenwerking tussen bedrijven. ${ }^{73}$ Maar de paradox is aan het verdwijnen: door de globalisering en met name de Europese integratie zijn de verhoudingen binnen het Nederlandse bedrijfsleven en de situatie op de binnenlandse markt liberaler geworden. ${ }^{74}$

72. Amable behandelt in de context van de reguleringstheorie de 'national systems of innovation approach'. Amable, 'Institutional complementarity and diversity of social systems' 664,669 .

73. Sluyterman, Kerende kansen, 324; Katzenstein, Small states in world markets, I05-I07.

74. Een belangrijk fenomeen is de mate waarin bedrijven samenwerken om innovatie tot stand te brengen. Het vermoeden is dat dit, al dan niet onder auspiciën van de overheid, ondanks de verdergaande liberalisering een heel belangrijke plaats blijft innemen. 


\section{Houding ten opzichte van het eigen personeel}

De mate waarin werknemers bij de besluitvorming worden betrokken en mogen meedelen in potentieel gevoelige informatie wordt misschien wel het beste aangegeven door het bestaan van de ondernemingsraad. Ieder bedrijf in Nederland met meer dan vijftig werknemers (voor I998 elk bedrijf met meer dan 35 medewerkers) is wettelijk verplicht een ondernemingsraad te hebben, waarbij het aantal werknemers bepalend is voor de omvang. De ondernemingsraad is een overlegorgaan waarin werknemers voor hun belangen in de organisatie kunnen opkomen en medeverantwoordelijk zijn voor het functioneren van de onderneming. Het is een voorbeeld van door de overheid geïnitieerde 'samenwerking', die weliswaar door de werkgeversorganisaties geregeld is tegengewerkt, maar toch een wezenlijk onderdeel is van het bestel. ${ }^{75}$ De wettelijke verplichting stamt uit I950. Na een aanpassing van de wet in I97I kreeg de ondernemingsraad meer bevoegdheden (op sommige punten evenveel recht als de aandeelhoudersvergadering). Vervolgens streefde de PvdA nog naar een verdergaande verzelfstandiging van de ondernemingsraad, waardoor het orgaan minder aan de leiband van de werkgever zou lopen; uiteindelijk werd er in I979 een duidelijker accent aangebracht op het werknemersbelang (naast het ondernemingsbelang) en mocht de werkgever niet meer de voorzitter leveren.

In Nederland hadden ondernemingsraden de afgelopen decennia een relatief sterke positie in de arbeidsverhoudingen, in zowel de interne als de externe belangenvertegenwoordiging..$^{6}$ Ze droegen bij aan de betrokkenheid van het personeel bij de onderneming. Zo had (en heeft) de ondernemingsraad dikwijls een stem in de onderhandelingen over een nieuwe CAO, vooral wanneer deze zich decentraal afspelen. De positie van de CAO is sinds de jaren tachtig sterker geworden, omdat veel aspecten van arbeidsrelaties en personeelsbeleid hierin geregeld worden. De dekkingsgraad van cao's in Nederland is internationaal gezien hoog. Naast bedrijfstak-CAO's zijn er ook de vele (kleinere) ondernemings-CAO's, waarbij de afspraken binnen het bedrijf gemaakt worden. In I986 waren er I9I bedrijfstak-CAO's en 590 ondernemings-CAO's. ${ }^{77}$

75. Doreen Arnoldus en Coen Helderman, 'Business Democracy as a Phantasm. Dutch employers' organised opposition against the works councils, I920-I980', paper gepresenteerd op congres van в в н а (European Business History Association) in Helsinki, 23-25 september 2002 .

76. Tros, Albeda en Dercksen, Arbeidsverhoudingen in Nederland,133-136; Sluyterman, Kerende kansen, I77-I79, I87-I88, 249-250; Peter Bootsma en Willem Breedveld, De verbeelding aan de macht. Het kabinet Den Uyl 1973-1977 (Den Haag I999) I95-I98.

77. In 2003 waren er I95 bedrijfstak-CAO's en 564 ondernemings-CAO's. Hieronder viel 74 procent van de werknemers. Van de overige 26 procent viel tien procent onder een overheidsregeling en zestien procent viel niet onder een CAO. W. Albeda en W.J. Dercksen, Arbeidsverhoudingen in Nederland (Alphen aan den Rijn I9894) 95; Tros, Albeda en Dercksen, Arbeidsverhoudingen in Nederland (20047) 99, I46. 
Om de betrokkenheid van werknemers te stimuleren en als manier om bedrijfsinformatie toegankelijk te maken voor het personeel, spelen de ondernemingsraden een rol die typerend is voor de c $\mathrm{m}$. Wel bestaat het vermoeden dat de toenemende internationalisering van het bedrijfsleven zal leiden tot een geringere rol van de ondernemingsraad. ${ }^{78}$ Voor het personeelsbeleid is ook de CAO een belangrijke institutie.

\section{Dynamiek van coördinatie: de hybride CME}

De Nederlandse economie was in de periode I950-I980 sterk gecoördineerd maar bewoog zich in de daaropvolgende decennia in de richting van een mengvorm met gecoördineerde en liberale kenmerken. Uit het bovenstaande blijkt dat in sommige deelgebieden Nederland sinds de jaren tachtig veel 'liberaler' is geworden: in [I] arbeidsverhoudingen; [3] beursfinanciering; en [4] binnenlandse concurrentie. In andere deelgebieden zijn de coördinatie-kenmerken sterker blijven voortbestaan: in [2] beroepsopleidingen; en in [5] personeelsbeleid en betrokkenheid van personeel. Coördinatie en overleg in sommige deelgebieden staan in contrast met het toenemend liberale karakter van de Nederlandse economie in andere deelgebieden.

Dit maakt Nederland tot een interessante casus voor de varieties of capitalism-theorie. De theorie stelt dat een economie waarin overleg tussen groepen met verschillende belangen een grote rol speelt, een andere sociale infrastructuur ontwikkelt dan een economie waarin het accent veel sterker ligt op conflict en eigenbelang. In Nederland zien we de afgelopen decennia tegengestelde bewegingen optreden in de institutionele deelgebieden. Maar de institutionele complementariteit stelt nu juist dat het meer voordelen geeft als de beweging in de verschillende deelgebieden dezelfde kant opgaat.

De theorie stelt dat binnen elke institutionele omgeving die oplossingen voor coördinatieproblemen worden gekozen die de meeste institutional complementarities in zich dragen. Toch zijn Hall en Soskice hierin niet consequent. Bij het voorbeeld van de wereldwijd toegenomen invloed van de internationale kapitaalmarkt (=liberalisering in deelterrein [3]) stellen Hall en Soskice dat dit in de C м E gepaard gaat met extra aandacht voor motivatie van personeel en het gelijktijdig afwijzen van typisch Angelsaksische managementtechnieken (=coördinatie in deelterrein [5]). ${ }^{79}$ Los van de vraag of dit in Nederland het geval is, kan men zich afvragen of hier niet sprake is van compensatie in plaats van complementariteit.

78. Jan Kees Looise en Michiek Drucker, 'Employee participation in multinational enterprises. The effects of globalisation on Dutch works councils', in: Employee Relations 24, I (200I) 29-52.

79. Hall en Soskice, 'Introduction', 6I-62. 
Volgens het feedback-mechanisme worden alle ontwikkelingen in de institutionele deelgebieden ingebed in de bestaande instituties en versterken ze daardoor de bestaande institutionele structuur. Dit klinkt een beetje tautologisch en geeft eigenlijk geen inzicht in verandering en economische dynamiek. De vraag dringt zich bijvoorbeeld op hoe je gezamenlijk (=gecoördineerd) afgesproken liberalisering moet beschouwen. Stel dat de SE R unaniem van mening is dat ontslagbescherming kan worden verminderd. Is dat een kenmerk van een hechte CME (centraal overleg tussen de sociale partners bepaalt het beleid) of van een beweging richting L $\mathrm{E}$ (de arbeidsmarkt wordt flexibeler en liberaler)? De theorie geeft hier geen duidelijk antwoord op.

De toenemende liberalisering van de wereldeconomie leidt tot druk op regeringen om tot belastingverlagingen, deregulering van de arbeidsmarkt en liberalisering van de interne markt te komen. Volgens de varieties of capitalism-theorie zal globalisering echter niet leiden tot wereldwijde convergentie, maar juist de twee 'oervormen' c m E en LM E versterken. ${ }^{8 \circ}$ Dit klinkt prettig als het gaat om de verdediging van het Europese model, maar de vraag komt op waarom alleen die twee extremen tegen globalisering zijn opgewassen. In de empirische toetsing van Hall en Gingerich wordt uitdrukkelijk gesteld dat de uitersten van het spectrum, de LME en de CME, de beste economische prestaties leveren. ${ }^{8 \mathrm{r}}$ Mengvormen met elementen uit de beide ideaaltypen zijn volgens hen minder levensvatbaar in een competitieve wereldeconomie en zullen op de lange duur een lagere economische groei hebben. Deze stelling wordt niet bevestigd door de economische groeicijfers van verschillende Europese landen gedurende de afgelopen decennia. Het is ook op theoretische gronden niet waarschijnlijk, omdat bepaalde instituties complementair zouden kunnen zijn met zowel instituties uit de CME als instituties uit de LME. ${ }^{82}$

In de dynamische wereldeconomie zoals die zich aan het eind van de twintigste eeuw heeft ontwikkeld, worden landen en bedrijven voortdurend ge-

80. Hall en Soskice spreken over een 'bifurcated response': in reactie op de globalisering zijn er twee beleidsopties, één van de LM E (verdergaande deregulering) en één van de CM E (cross-class coalitions with interests in regulatory regimes) (p. 58).

81. Het bewijs van deze stelling is nogal omslachtig en komt nogal hypothetisch over. Hall en Gingerich, 'An empirical analysis', table 4 en figure 3.

82. Wanneer veranderingen in de jaren tachtig en negentig in kaart worden gebracht, blijken de см в en de Lм в niet in alle opzichten te divergeren. Op het gebied van bijvoorbeeld vakbondsdichtheid en dekking van onderhandelingen is de afname in de LM E'S groot, in de CME's gering. Stock market capitalisation neemt toe in CME'S maar nog sterker in LME's. Arbeidskosten per eenheid product stijgen in CM E's maar stijgen nog harder in LM E's. In ontslagbescherming treedt weinig verandering op, die blijft hoger in CM E's. Arbeidsmarktflexibiliteit (aantal part-timers, gemiddeld aantal arbeidsuren) verandert min of meer op gelijke voet in см E's en Lm E's. Zie Hall en Gingerich, 'An empirical analysis' tabel 8 (p. 43) en Hall en Soskice, 'A response to three critics', tabel I (p. 247). 
dwongen veranderingen aan te brengen in hun institutionele structuur. ${ }^{83}$ Allerlei transformaties doen zich voor: deregulering van financiële markten, sterkere verantwoordelijkheden voor de individuele burger (met name met betrekking op pensioenen en gezondheidszorg), sterke uitbreiding van multinationale bedrijfsactiviteiten (waarmee bedrijven zich deels kunnen onttrekken aan het nationale vigerende systeem van bijvoorbeeld arbeidsverhoudingen of andere coördinatiemechanismen) en vormen van internationale beleidsharmonisatie (waardoor bijvoorbeeld het kartelverbod strenger wordt gehanteerd). ${ }^{84}$ Het is onvermijdelijk dat veranderingen in sommige deelgebieden afbreuk doen aan de institutional complementarities. Toch kan het voordeel van hervorming in een bepaald deelgebied groter zijn dan het relatieve verlies aan comparative institutional advantage. Het kan ook zijn dat verschillende beleidsalternatieven elk compatibel zijn met de overige instituties in het land, zodat de institutionele complementariteit niet slechts één type hervorming dwingend voorschrijft.

Kan een mengvorm tussen LM E en см wel blijven bestaan, zonder de kruisbestuiving van institutional complementarities? Een criticus, Goodin, postuleerde dat, wanneer de optimale CM E wordt verlaten, een economie in versneld tempo zal afglijden naar het liberale type, omdat het wederzijds vertrouwen (trust) waarop de gecoördineerde markteconomie is gebaseerd, over het algemeen moeizaam tot stand komt en des te gemakkelijker weer wordt afgebroken. ${ }^{85}$ Hall en Soskice stelden daar tegenover dat instituties robuust zijn omdat er permanent over wordt onderhandeld: het zijn flexibele verzamelingen regels en verstandhoudingen die de verschillende vormen van coördinatie ondersteunen. ${ }^{86}$ De voortdurende onderhandelingen die plaatsvinden, maken het systeem niet fragiel maar sterk: men is gewend met elkaar in contact te staan en oplossingen of compromissen te zoeken. De partijen hechten belang aan strategische coördinatie en ondersteunen gezamenlijk bepaalde vormen van regulering.

83. Ook hier is het zinvol om onderscheid aan te brengen tussen grote en kleine landen. Becker en Schwartz betogen dat kleine landen een apart type markteconomie hebben omdat ze toch al open en prijsbewust zijn. Hierdoor biedt globalisering juist méér groeikansen. Uwe Becker en Herman Schwartz (eds.), Employment 'miracles': a critical comparison of the Dutch, Scandinavian, Swiss, Australian and Irish cases versus Germany and the US (Amsterdam 2005) 26.

84. Zie ook Amable, 'Institutional complementarity and diversity of social systems', 666-667.

85. Robert E. Goodin, 'Choose your capitalism', in: Comparative European Politics I (2003) 203-213.

86. Hall en Soskice, 'Introduction', 5, 9-I2. Zie ook: Peter A. Hall en David Soskice, 'Varieties of capitalism and institutional change: a response to three critics,' in: Comparative European Politics I (2003) 24I-250. 
Ook in de Nederlandse situatie komt duidelijk naar voren dat het geïnstitutionaliseerd overleg sterk verankerd is. De maatschappelijke waardering voor herverdeling (met name in de sociale arrangementen van de verzorgingsstaat) blijkt vooralsnog hoog te zijn. ${ }^{87}$ Een gevolg van de 'robuustheid' van overleg kan zijn dat wanneer er op specifieke knelpunten een verregaande deregulering of hervorming wordt nagestreefd, niet meteen het gehele overleggebouw zal wankelen. Het zou vreemd zijn als Nederland ervoor moest vrezen dat enkele liberale kenmerken de gecoördineerde economie zullen ondermijnen. Desondanks is in de varieties of capitalism-theorie voor mengvormen uiteindelijk geen plaats.

\section{Conclusie}

De varieties of capitalism-theorie biedt een interessant conceptueel kader voor de analyse van institutionele verschillen tussen landen. Maar de criteria in de theorie zijn van abstracte (zo niet vage) aard en zijn moeilijk te toetsen. De aandacht voor context en geschiedenis is een pre, maar de theorie is voor de historicus moeilijk te operationaliseren. Het idee dat complementaire instituties optreden in deelgebieden is inzichtelijk, maar geeft geen ruimte voor het verklaren van tegengestelde ontwikkelingen in de verschillende deelgebieden.

Hall en Soskice benadrukken dat de instituties van de politieke economie nauw verweven zijn met hun geschiedenis: niet alleen is hun ontstaan padafhankelijk, ook scheppen zij een bepaald verwachtingspatroon bij bedrijven en organisaties. De ervaringen uit het verleden maken efficiënt overleg mogelijk en leiden tot betrouwbare afspraken. Op deze wijze ontstaat een goede verklaring voor verschillende levensvatbare vormen van markteconomieën (de LM E en de см E). Voor het analyseren van structurele verandering schiet de theorie echter tekort. Padafhankelijkheid wordt niet expliciet geanalyseerd en blijft een 'black box'.

Dit wordt geillustreerd door de positie van Nederland, die in internationale vergelijking een interessante mengvorm blijkt te zijn tussen een LME en een C M E. Tijdens de laatste decennia van de twintigste eeuw zijn sommige institutionele deelterreinen ingrijpend hervormd, geliberaliseerd of gedereguleerd, terwijl op andere terreinen de coördinatiekenmerken in stand zijn gebleven. Toch kan moeilijk gesteld worden dat de Nederlandse economie sinds de jaren negentig minder succesvol was dan de Duitse, of dat de veranderingen in de Nederlandse structuur nadelig waren voor de economische ontwikkeling. De toegenomen dynamiek in de arbeidsmarkt wordt door velen juist beschouwd

87. Sociaal Cultureel Planbureau, Sociaal en cultureel rapport 1998. 25 jaar sociale verandering (Den Haag I998) II2-II3. 
als een belangrijke verbetering. Nederland valt moeilijk in te passen in de rigoureuze tweedeling en lijkt het principe van institutionele complementariteit te logenstraffen. De conclusie moet luiden dat er vitale mengvormen bestaan van gecoördineerde en liberale markteconomieën, omdat het mogelijk is om binnen een overlegcultuur sommige deelgebieden sterker door de markt te laten regeren dan andere. De Nederlandse casus kan door de varieties of capitalism-theorie niet goed worden verklaard.

Het ééndimensionale karakter van de theorie, waarin 'coördinatie' als het enige criterium wordt gehanteerd, is niet alleen onbevredigend omdat mengvormen worden ondergewaardeerd, maar ook omdat verschuivingen en evoluties binnen elk ideaaltype niet goed in kaart kunnen worden gebracht. De vijf institutionele deelgebieden uit de theorie bleken in dit artikel goede aanknopingspunten te bieden om een wisselende mate van dynamiek in kaart te brengen, maar volgens de theorie zou het mechanisme van institutional complementarities juist voor een eenvormige ontwikkeling in al deze gebieden moeten zorgen. Hoe kunnen dan hervormingen in specifieke deelgebieden worden geanalyseerd, als zij leiden tot vernieuwde configuraties bínnen de CM E of de LM E?

Institutionele complementariteit sluit in theorie niet uit dat er op een bepaald deelgebied in verschillende landen geheel eigen ontwikkelingen optreden die elk weer complementair zijn met de overige instituties in het land. Het zou wenselijk zijn dat in kaart te brengen. Wordt naast 'de mate van coördinatie tussen bedrijven' een tweede dimensie onderscheiden, bijvoorbeeld 'de mate van overheidsregulering' of 'de mate van decentralisatie', dan kunnen institutionele ontwikkelingen binnen de groep van CM E's of LM E's duidelijker tegen elkaar worden afgezet. Zo kunnen bijvoorbeeld veranderende wetgeving in reactie op de toenemende globalisering, decentralisering van overleg in de arbeidsverhoudingen, of bepaalde vormen van door de overheid gestimuleerd innovatiebeleid, leiden tot een minder centraal gereguleerde c m E. Deze ontwikkelingspaden kunnen dan elk op hun merites worden beoordeeld. De varieties of capitalism-theorie geeft een inzichtelijk kader voor de analyse van institutionele kenmerken, maar de roep is om meer dimensies en meer aandacht voor dynamiek.

\section{Over de auteur}

Jeroen Touwen promoveerde in I997 aan de Universiteit Leiden op het proefschrift Extremes in the archipelago. Trade and economic development in the Outer Islands of Indonesia, 1900-1942 (Handelseditie: Leiden, KITLV Press, 200I). Hij is verbonden aan de Opleiding Geschiedenis in Leiden en doet momenteel onderzoek naar de economische geschiedenis van Nederland in comparatief opzicht.

E-mail: 1.j.touwen@let.leidenuniv.nl 